\title{
Structure and emplacement of the South Mountain Batholith, southwestern Nova Scotia
}

\author{
R.J. Horne, M.A. MacDonald, M.C. Corey and L.J. Ham \\ Nova Scotia Department of Natural Resources, P.O. Box 698, Halifax, Nova Scotia B3J 2T9, Canada
}

\author{
Date Received January 28, 1992 \\ Date Accepted April 23, 1992
}

\begin{abstract}
The South Mountain Batholith (SMB) is a large, ca. $370 \mathrm{Ma}$, composite intrusion which was emplaced after deformation associated with the Middle Devonian Acadian Orogeny. Structures in the SMB include primary flow features, NE-trending faults $\left(\approx 045^{\circ}\right.$ ) and fractures (at $040^{\circ}$ and $062^{\circ}$ ) and NW-trending faults and joints (at $315^{\circ}, 325^{\circ}$ and $335^{\circ}$ ). Joint trends are regional in nature, showing no relationship to intrusive features. Granite-related dykes, veins, alteration and mineralization in the faults and joints indicate a primary-regional status for these structures. NEtrending fractures are interpreted as $\mathrm{P}$ and $\mathrm{R}$ shears (Riedel geometry) associated with dextral displacement on the NEtrending faults, whereas NW-trending joints are interpreted as tension joints and attending conjugate-shear joints of small dihedral angle reflecting NW-transpression during intrusion. Repetitive joint and fault development continued into the Permian, implying a fixed regional stress through this interval.

The joint and fault systems in the SMB strongly influenced the localization and character of granite-related mineralization. Sn-W-Cu-Mo quartz-greisen veins occur in NW-trending joints, whereas U-Mn mineralization occurs in NE-trending faults and associated fractures.

Localization of the batholith is inferred to have been strongly influenced by regional, NE-trending faults which were active during granite intrusion and responsible for localization of some of the later plutons. Final emplacement was largely accomplished by stoping, which was strongly influenced by NE- and NW-trending structures developed in the country rocks and early units of the batholith.
\end{abstract}

Le batholite du mont South est une intrusion composite volumineuse, datée à environ $370 \mathrm{Ma}$, qui s'est mise en place après la déformation associée à l'orogénèse acadienne du Dévonien moyen. Les éléments structuraux observés dans le batholite comprennent des structures d'écoulement primaires, des failles (à environ $045^{\circ}$ ) et des fractures (à $040^{\circ}$ et $062^{\circ}$ ) de direction nord-est et des failles et des joints de direction nord-ouest (à $315^{\circ}, 325^{\circ}$ et $335^{\circ}$ ). Les directions des joints correspondent aux orientations régionales et ne montrent pas de relation avec les structures intrusives. Les dykes, les veines, l'altération, la minéralisation reliés au granite dans les failles et les joints indiquent qu'il s'agit de structures primaires à distribution régionale. Les fractures nord-est sont interprétées comme étant des cisaillements $\mathbf{P}$ et $\mathbf{R}$ (géométrie de Riedel) reliés à un déplacement dextre des failles nord-est, tandis que les joints nord-ouest sont interprétés comme étant des joints d'extension auxquels sont associés des joints de cisaillement conjugués de petit angle dièdre qui reflétent une transpression nord-ouest pendant l'intrusion. Le développement répété de joints et de failles a continué jusqu'au Permien, indicant une contrainte régionale fixe pendant cet intervalle.

Les systèmes de failles et de joints dans le batholite du mont South ont fortement influencé la position et le caractère de la minéralisation reliée au granite. Les veines de greisen quartzifère à $\mathrm{Sn}$-W-Cu-Mo occupent des joints nord-ouest tandis que la minéralisation en U-Mn se retrouve dans des failles nord-est et des fractures associées.

La position du batholite est interprétée comme ayant été fortement influencée par les failles régionales nord-est qui étaient actives lors de l'intrusion des granites et qui sont responsables de la localisation de certains plutons tardifs. La mise en place finale s'est effectuée en grande partie par effondrement du toit, qui a été fortement influencé par les structures nord-est et nord-ouest développées dans les roches encaissantes et les unités précoces du batholite.

[Traduit par le journal]

\section{INTRODUCTION}

The South Mountain Batholith (SMB) is one of the largest $\left(\approx 7300 \mathrm{~km}^{2}\right)$ granitoid exposures in the Appalachian Orogen and occupies a large part of southwestern Nova

Contribution to the Canada-Nova Scotia Mineral Development Agreement, 1984-1989

ATLANTIC GEOLOGY

28. 29.50 (1992)
Scotia (Fig. 1). A detailed (1:50,000 scale) mapping program, initiated by the Nova Scotia Department of Mines and Energy, was carried out over the SMB by the authors from 1985 to 1989 . This survey represents the first detailed assessment of this composite intrusion. The following paper addresses structural data collected during this mapping, including primary flow features, fracture patterns and faults. A previous paper on the structure of the eastern part of the SMB (Horne et al., 1988) identified a rectilinear pattern of pri- 


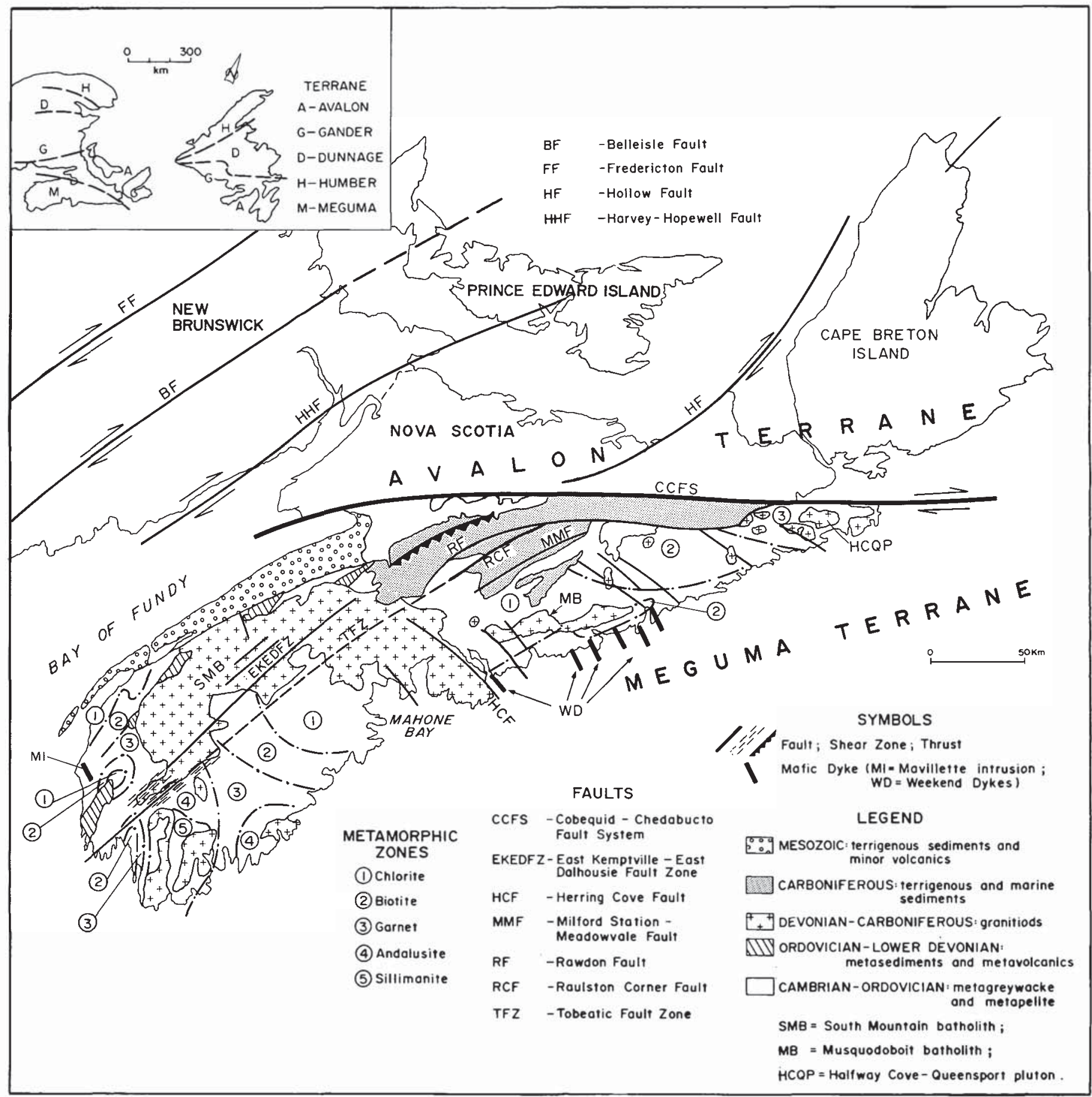

Fig. 1. General geological map of the Meguma Terrane showing the geological setting of the South Mountain Batholith.

mary-regional joint and fault trends parallel and normal to Appalachian Orogen trends, interpreted to reflect active, regional stress during intrusion. These structures influenced vein and dyke orientations, localization of granite-related mineralization and final stages of emplacement of the batholith. The following paper extends the assessment of structure to the entire SMB and discusses the influence of primaryregional structures on the localization of mineralization and emplacement of the batholith, and the implications for regional tectonics.

\section{Geological Setting}

The SMB is a large, peraluminous, epizonal intrusion occurring in the Meguma Terrane, the easternmost terrane of the Appalachian Orogen (Fig. 1). The Meguma Terrane is dominated by a conformable sequence of Cambrian to Ordovician metagreywacke-metapelite (Meguma Group) and Late Ordovician to Lower Devonian metasedimentary-metavolcanic rocks and Devonian to Carboniferous granitoid rocks, including SMB (Fig. 1). These rocks are unconformably 
overlain by Carboniferous sedimentary rocks. The SMB is post-tectonic, truncating regional NE-trending folds developed during the Middle Devonian Acadian Orogeny. A ca. $370 \mathrm{Ma}$ age for the batholith has been established by isotopic dating (Chatterjee and Ham, 1991; Harper, 1988), consistent with stratigraphic limitations imposed by its intrusion into the Emisian Torbrook Formation and the age of the overlying Lower Tournaisian Horton Group (Utting et al., 1989). Several features indicate that the Meguma Terrane experienced protracted, intermittent or progressive, moderate, NW-directed transpression until the Permian. These include: (i) dextral, strike-slip movement on the Cobequid-Chedabucto and Hollow fault systems (Fig. 1) from Middle Devonian to Late Carboniferous (Mawer and White, 1987; Keppie, 1982; Yeo and Ruixiang, 1986; Webb, 1969; Esibacher, 1969), (ii) regional, northwest-shortening (thrusting, folding, strikeslip faulting) of Upper Paleozoic sedimentary basins in the Maritime region (Nance, 1987; Boehner, 1991, in press; Lajtai and Stringer, 1981); and (iii) northeast-trending, dextral shearing in the Meguma Terrane from the Late Devonian to Permian (Kontak et al., 1989; Dallmeyer and Keppie, 1987).

\section{Geology of the South Mountain Batholith}

A detailed account of the geology of the SMB is given in MacDonald et al., 1992. A generalized map reflecting this work in shown in Figure 2a. The batholith comprises numerous map bodies, which, on the basis of lithologic and textural similarities, naturally group into six main rock types (see legend Fig. 2a). Thirteen plutons have been defined within the SMB by cross-cutting relationships of regional lithologic-petrographic and (or) chemical zonation (see MacDonald et al., 1992); plutons define a distinct intrusive event and vary in complexity from singular to composite intrusions. Lithologic and relative age characteristics of the thirteen plutons allow them to be categorized into two temporal-lithologic groups referred to as stage 1 and stage 2 plutons (Fig. 2b). Stage 1 plutons are dominated by biotite granodiorite and biotite monzogranite and were invariably intruded by stage 2 plutons, which are dominated by leucomonzogranite and leucogranite (compare Fig. 2a and b). Recent geochronological studies indicate that both stage 1 and stage 2 plutons were intruded at roughly $370 \mathrm{Ma}$ (Chatterjee and Ham, 1991; Harper, 1988; M.A. MacDonald, per. com., 1990).

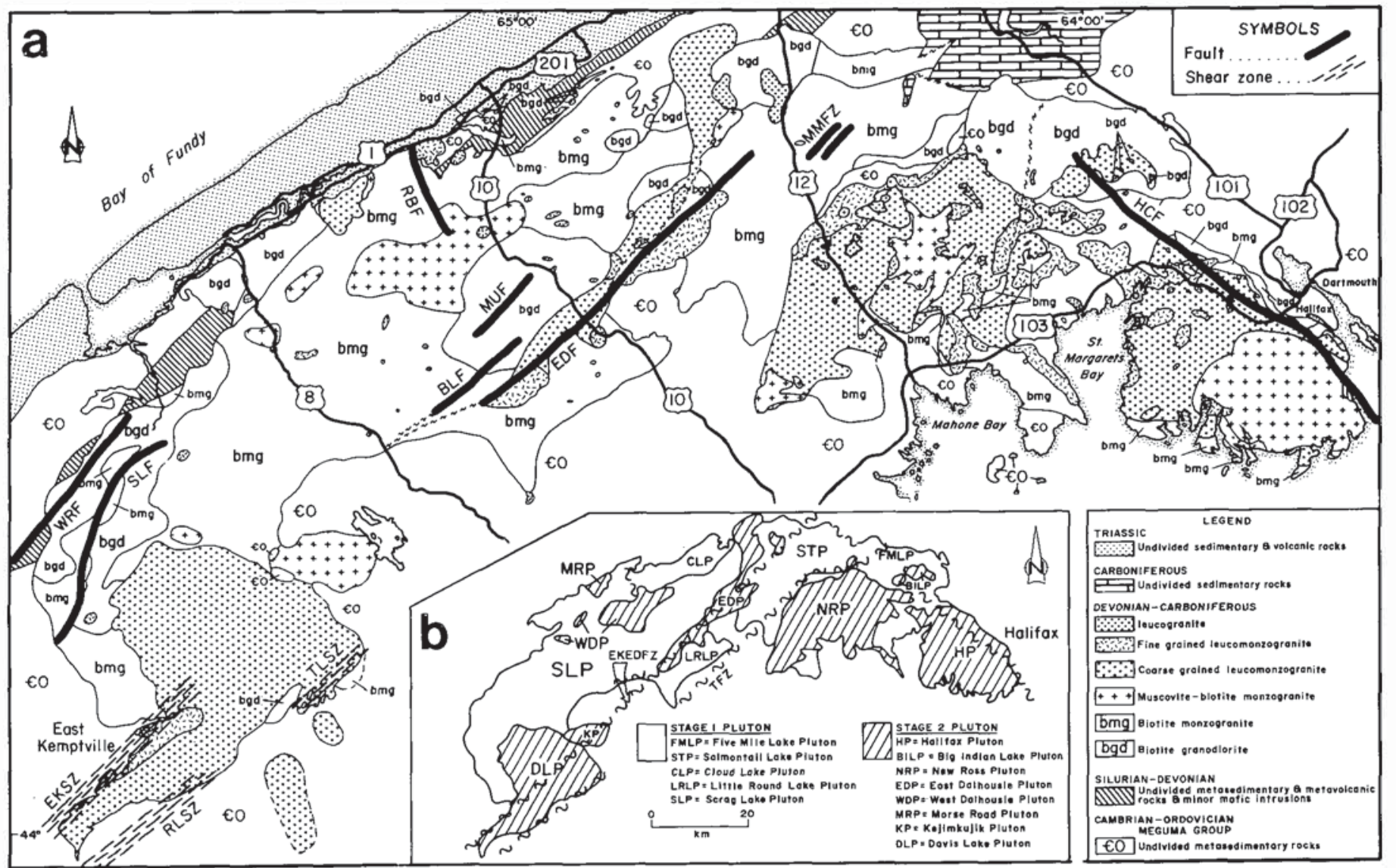

Fig. 2. Geological map of the South Mountain Batholith showing the distribution of the various lithologic units and the location of the major fault and shear zones. Inset map outlines the distribution of plutons. BLF - Beaver Lake fault; EDF - East Dalhousie fault; EKEDFZ - East Kemptville - East Dalhousie fault zone; EKSZ - East Kemptville shear zone; HCF - Herring Cove fault; MMFZ - Manganese Mines fault zone; MUF - Molly Upsim fault; RBF - Roxbury Brook fault; RLSZ - Rushmeer Lake shear zone; SLF - Sissiboo Lake fault; TFZ - Tobeatic fault zone; TLSZ - Tobeatic Lake shear zone; WRF - Wallace River fault. 


\section{Primary Flow Structures}

Upon initial investigation, the SMB typically appears massive and homogeneous, lacking conspicuous internal structure. However, various local- and regional-scale planar and non-planar, primary flow structures have been recognized. These include widespread megacryst-xenolith alignment, local biotite alignment and rare occurrences of schlieren, megacryst and (or) xenolith concentrations, and rhythmic layering.

\section{Megacryst - Xenolith Alignment}

Alignment of megacrysts and, less commonly, xenoliths is the most common and widespread primary flow structure in the SMB. Megacryst alignment is defined by parallel alignment of the apparent long axis of tabular feldspar megacrysts in plan section and varies from weakly to strongly developed. At the outcrop scale megacryst alignment defines both planar and irregular (swirling) patterns. The flat nature of most outcrop in the SMB hinders evaluation of the three-dimensional character of this fabric, however, where noted in local vertical exposures it generally defines a steeply dipping layering (foliation). No lineation has been identified, largely due to the difficulty in establishing the long axis of tabular crystals. Xenolith alignment is defined by the long axis of elongate xenoliths in plan section and, where present, generally parallels megacryst alignment.

The trend of megacryst alignment showing a linear, consistent orientation at the outcrop scale was recorded during regional mapping. Compilation of these data indicates apparently, regional, batholith- and pluton-scale patterns (Fig. 3). The best developed and most convincing is a linear, NE-trending pattern parallel to the long axis of the western part of the batholith (Fig. 3). This linear pattern was previously recognized by McKenzie (1974) and Smitheringale (1973). Less convincing, possible circular patterns are centred on the Halifax and New Ross plutons (Fig. 3); these are best developed in the Halifax pluton where megacryst alignment and schlieren locally conform to the margin of the pluton.

A comprehensive, detailed investigation of preferred megacryst alignment was documented by Abbott (1989) for two areas near the eastern end of the SMB. That study demonstrated that aligned megacrysts define well-developed, complex patterns at the scale of 100 to $500 \mathrm{~m}$ (Fig. 4). These structures have been interpreted to reflect variable deformation, including shearing, related to stress by viscous flow within the magma during intrusion/emplacement (Abbott, 1989). As outlined by Abbott (1989), similar complex patterns at this scale are unknown in other intrusions, suggesting they are either unique or, more likely, unrecognized elsewhere; indeed recognition of these patterns is only possible by painstakingly detailed, objective mapping.

\section{Biotite Alignment}

A distinct foliation defined by biotite and, less commonly, feldspar augen is locally developed within the south-

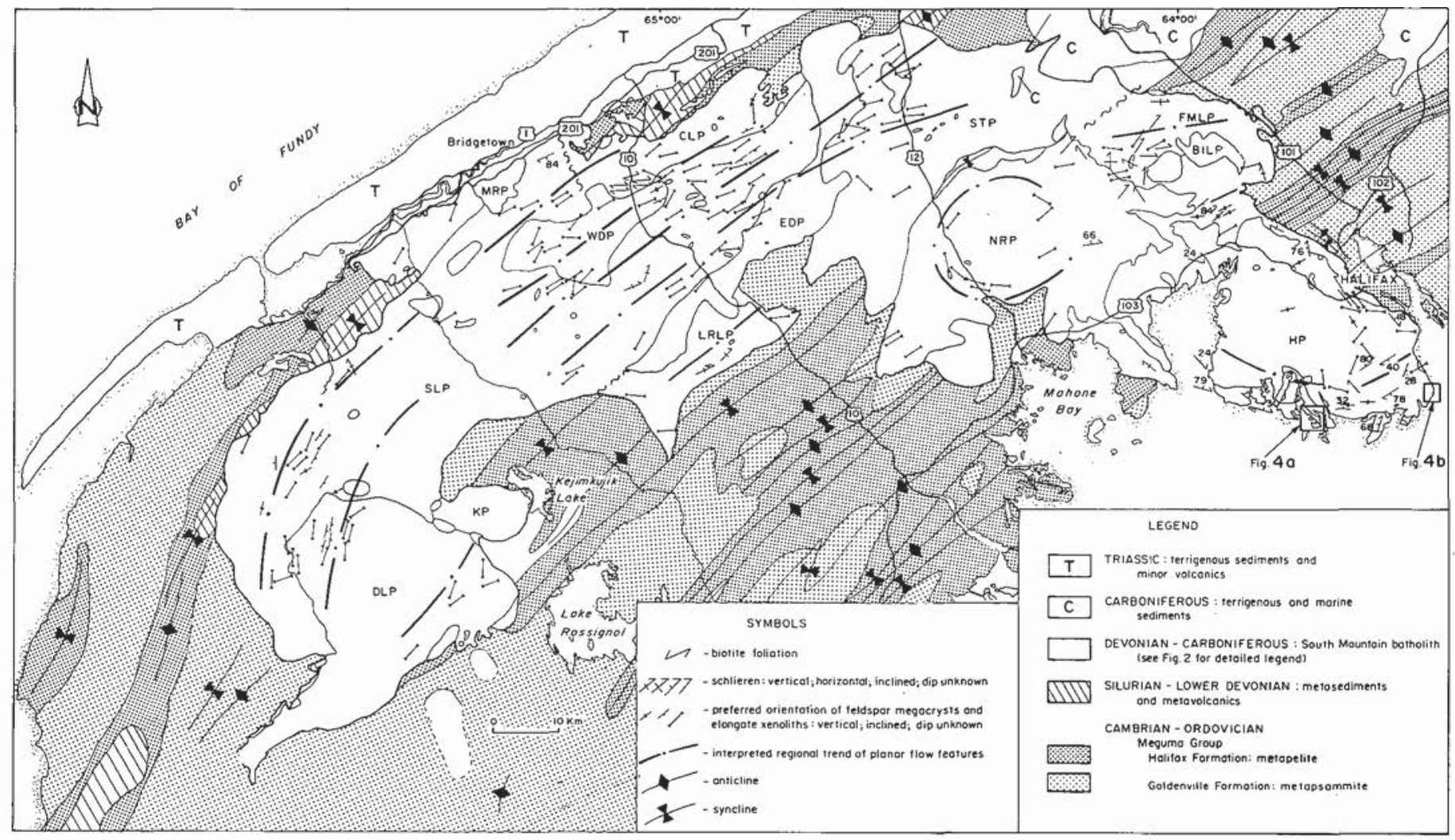

Fig. 3. Map of primary flow features and interpreted regional trends in the South Mountain Batholith. 


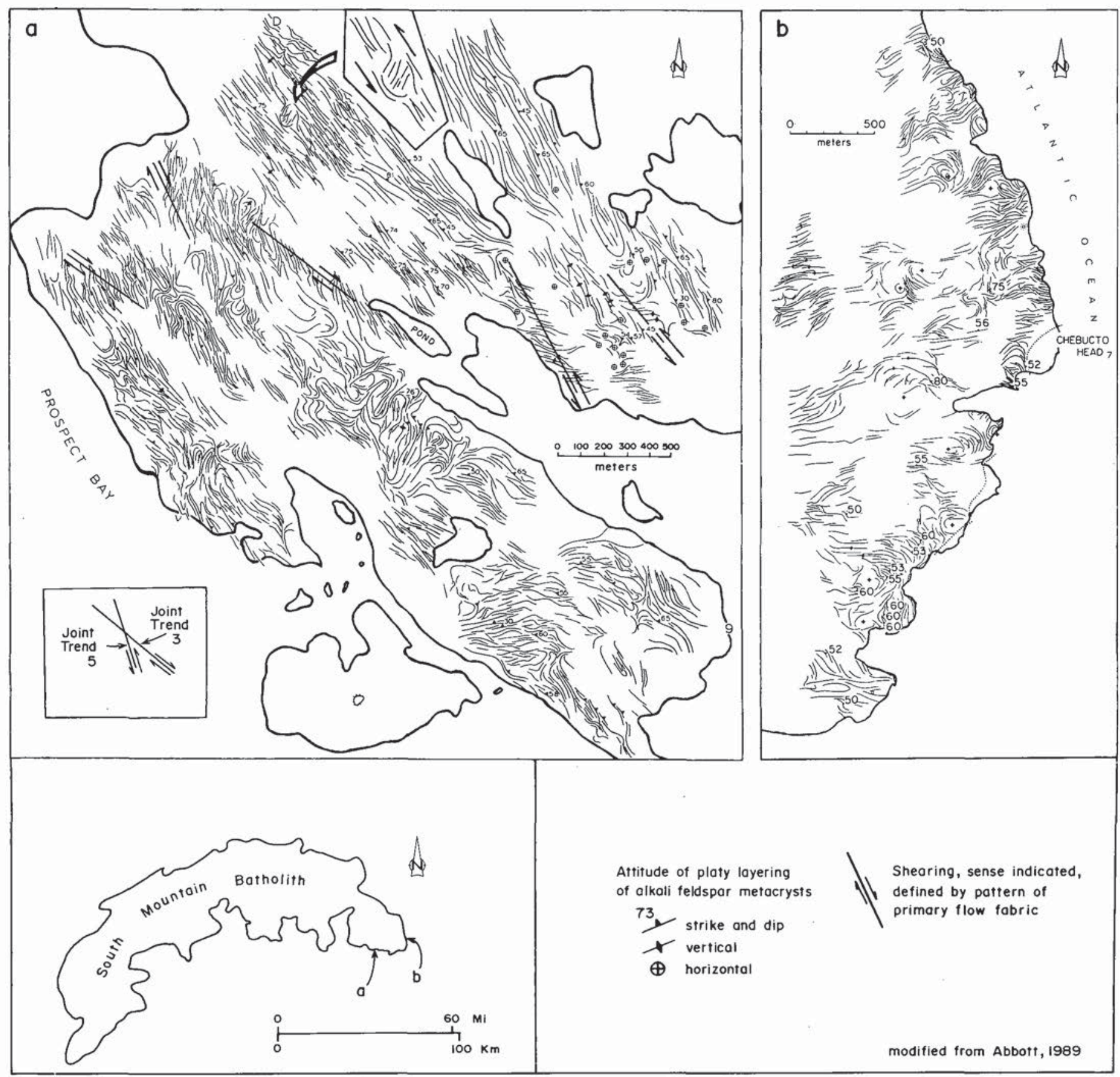

Fig. 4. Map of local-scale, primary flow patterns defined by aligned megacrysts (platy layering of alkali-feldspar megacrysts) in the Prospect Bay (a) and Chebucto Head (b) areas (after Abbott, 1989). Location of both areas shown on inset map and Figure 3. Note welldefined NW planar fabric and associated asymmetric folds, and apparent metre-scale, rotated augen structure (arrow) in (a), all implying NW shearing (dextral and sinistral). Inset figure in (a) shows the orientations of conjugate primary-regional, NW-trending shear joints in the South Mountain Batholith (see discussion on joints in text for explanation).

ern part of the Cloud Lake pluton, in the area adjacent to the West Dalhousie pluton (Fig. 3). This foliation trends NE, parallel to the trend of megacryst alignment in this area (Fig. 3). The foliation is heterogeneously developed and foliated rocks grade to adjacent, unfoliated rocks (MacDonald and Ham, 1988, 1989; Smitheringale, 1973; McKenzie, 1974), suggesting that the foliation may reflect shearing. The zone of biotite foliation is apparently truncated by the West
Dalhousie pluton implying that foliation development occurred in the interval between intrusion of stage 1 and stage 2 plutons.

\section{Isolated Schlieren, Xenolith-Megacryst Concentrations and Rhythmic Layering}

Schlieren, typically consisting of isolated biotite-rich 
layers, are found sporadically throughout the batholith (Fig. 3). Development of schlieren within the batholith is not well understood. However, they commonly parallel megacryst alignment and are interpreted to reflect differential flow within the magma. Anomalous concentrations (pockets) of xenoliths and (or) megacrysts uncommonly occur throughout the SMB and are interpreted to reflect concentration by flowage differentiation (Horne et al., 1988; Clarke and Chatterjee, 1988). A rare occurrence of 'rhythmic layering', consisting of altemating mafic and leucocratic layers displaying features similar to graded bedding and cross-bedding, has been documented in the eastern end of the SMB (Smith, 1975; Clarke and Muecke, 1980; Abbott, 1989). Contrasting models for the origin of this layering have been proposed (Smith, 1975; Clarke and Muecke, 1980).

\section{Discussion}

The features discussed above, including schlieren, megacryst-xenolith concentrations, megacryst-xenolith alignment and biotite alignment, are primary, flow-related features reflecting differential flow in the magma during intrusion. Many of these features, such as local swirling patterns defined by aligned megacrysts, megacryst-xenolith concentrations and possible regional, circular patterns defined by aligned megacrysts, reflect convection and internal stress during intrusion. Conversely, well-developed regional patterns defined by aligned megacrysts, xenoliths and biotite, which show no obvious relationship to intrusions, imply that their development was influenced by external stress imposed on the batholith.

Abbott (1989) interpreted the complex, local patterns of aligned megacrysts in the two areas he studied (Fig. 4) as reflecting deformation in the magma due to 'internal stress, being passively imposed by the surrounding rocks'. This conclusion was largely based on an apparent lack of syn- and post-emplacement deformation within the SMB. However, the work presented in this paper demonstrates that a regional, albeit moderate, NW-directed compressional stress existed during granite intrusion and resulted in syn- and post-emplacement deformation. The orientation of and sense of shear on NW-trending shear zones defined by aligned megacrysts (Fig. 4a) correspond to primary-regional conjugate shear joints which reflect regional NW-compression (see joints below), implying that flow deformation reflected external regional stress.

Recognition of the complex patterns of aligned megacrysts at the scale defined by Abbott (1989) brings into question the significance of regional patterns such as those shown in Figure 3. Indeed, interpretation of circular patterns associated with the New Ross and Halifax plutons are ques- tionable. However, the consistent trend of aligned megacrysts-xenoliths and aligned biotite in the western part of the SMB, defining a regional NE-trending pattern parallel to the long axis of the batholith and regional structures in the country rocks implies this pattern is real and significant. The origin of this pattern has not been established, however, its regional nature implies a regional cause. Conformity of this pattern with regional structure suggests it may reflect regional tectonic stress during intrusion. On the other hand, this pattern conforms to the shape of the Scrag Lake pluton, swinging to the south at the western end of the batholith, and therefore may reflect internal stress related to 'ballooning' during intrusion.

\section{JoInts, Dy Kes and Veins}

\section{Joints}

\section{Orientation}

The attitude of prominent joints were recorded at approximately two thousand outcrop locations within the SMB during regional mapping. Contoured density stereoplots have been produced for these data to evaluate the presence of systematic joint patterns. In order to assess the influence of geographic distribution or intrusive features on joint patterns, stereonets of joint data were produced for each, or part of each, NTS map sheet (Fig. 5A-N) as well as data sets reflecting three stage 2 plutons (Fig. 5P,Q,R). In addition, stereonets were produced for compiled data sets of joints for the areas east and west of the Tobeatic fault zone (Fig. 5O,R). This division was made to assess any variation across this structure and is reflected in the subdivision of some of the NTS map sheets (e.g., Fig. 5D,J). The results indicate that a repetitive, roughly orthogonal pattern, defined by maxima, or set of submaxima, representing steeply dipping northeastand northwest-trending joints dominate the stereoplots of nearly all data sets.

The general northwest trend is defined by a broad, consistent sequence of contours which is everywhere constant in orientation (Fig. 5). Maxima and submaxima (represented by the highest contour interval), however, define three separate trends, for example, in Figure 5A, C and $\mathrm{K}$. On these stereoplots, contour intervals lower than $6 \%$ form a smooth conformable sequence centred about a general northwest trend, whereas the 6 to $8 \%$ contour defines maxima and (or) submaxima reflecting three separate trends; one consistent with the average (bisector) of the entire conformable sequence at $\approx 325^{\circ}$ (e.g., Fig. 5E), and the other two concentrically arranged about this trend at $\approx 315^{\circ}$ (e.g., Fig. $5 \mathrm{~J}, \mathrm{M}$ ) and $\approx 335^{\circ}$ (e.g., Fig. 5G,J). The regional significance of all three joint

Fig. 5. Contoured density plots of poles to joints (in 1\% area) in parts of the South Mountain Batholith: (A-N) joints from each, or parts of each, NTS map sheet (inset map). Subdivision of some map sheets reflects the Tobeatic fault zone (see text for discussion); (O) joints in the East Dalhousie pluton (index map); (P) joints in the New Ross pluton (index map); (Q) joints in the Halifax pluton (index map); (R) joints compiled for the area west of the Tobeatic fault zone (i.e., A-F); (S) joints compiled for the area east of the Tobeatic Fault Zone (i.e., G-N). 

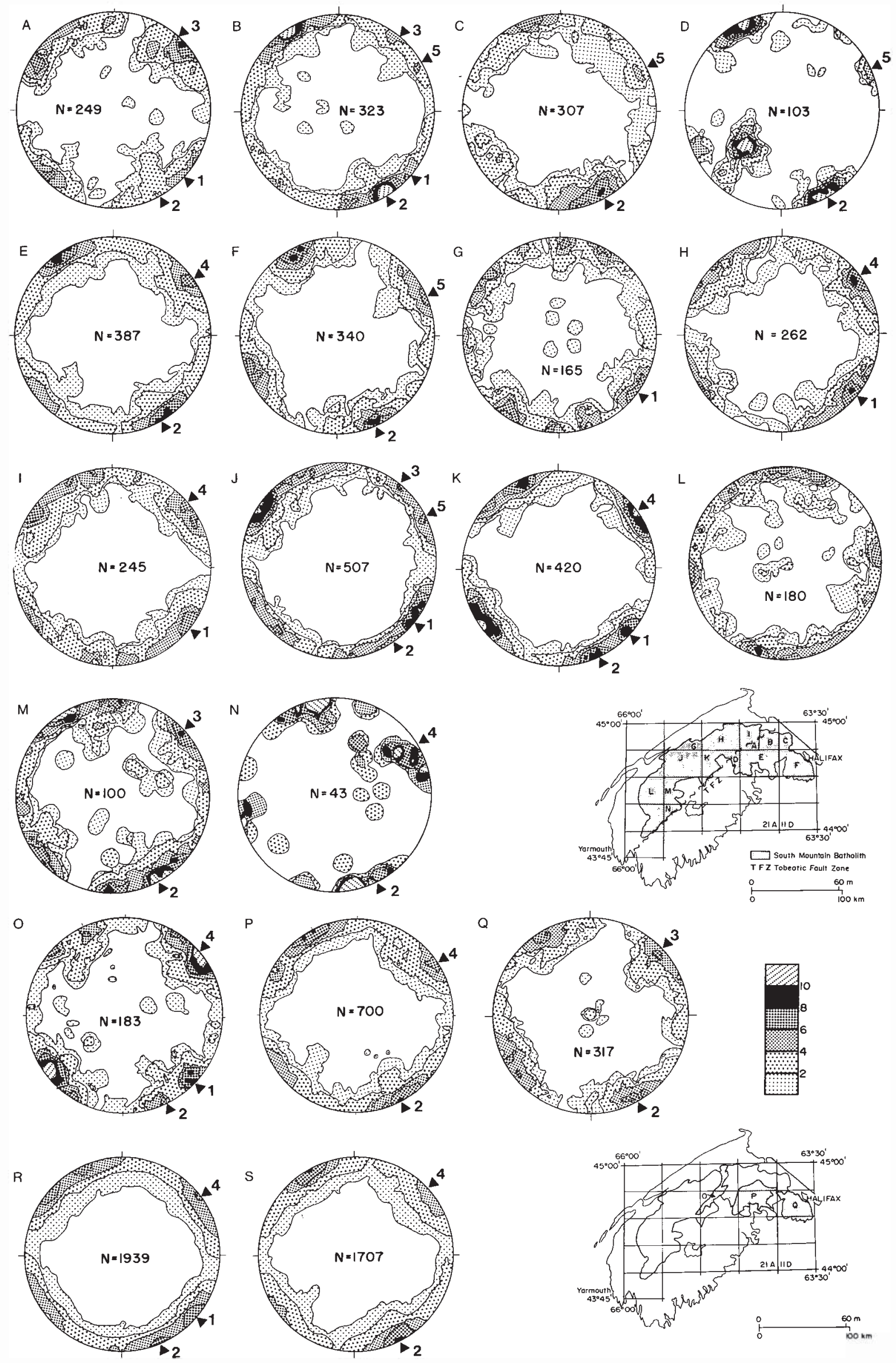
trends is shown by repetition in several data sets, with no submaxima falling between them, their representation by dykes and veins within the SMB and their representation by joint, vein and dyke trends elsewhere in the region (Table 1).

The general northeast trend is defined by a broad se-

Table 1. Joint, dyke and vein trends in the SMB, selected ca. 370 Ma plutons of the Meguma Terrane and selected pre- and post-SMB rocks of the Maritime region.

Trend 1 Trend 2 Trend 3 Trend 4 Trend 5

\section{Cover Rocks \\ Joints \\ Lajtai and Stringer'
Gillis $^{2}$
O'Brien $^{3}$
$\quad(n=249)$}

040

065

315

325

NE

NW

323

South Mountain Batholith

\section{Joints east of TFZ \\ NTS11D/12 (N=340) \\ NTS11D/13 $\quad(n=307)$ \\ NTS21A $09 \quad(n=387)$ \\ NTS21A/10 ( $\mathrm{n}=103)$ \\ NTS21A/16E $\quad(n=323)$ \\ NTS21A/16W $\quad(n=249)$}

Joints west of TFZ

NTS21A/16W $\quad(n=245)$

NTS21A/10 $(\mathrm{n}=420)$

NTS21A/11 ( $n=507)$

NTS21A/14 $(n=165)$

NTS21A/03 $(n=43)$

NTS21A/OS $\quad(n=180)$

NTS21A/06 $\quad(n=100)$

NTS21A/15 (n=262)

Joints compiled

East $^{6} \quad(n=1707)$

West ${ }^{7} \quad(n=1939)$

HP $^{8} \quad(\mathrm{n}=317)$

NRP $\quad(\mathrm{n}=700)$

EDP10 ( $\quad(n=183)$

Charest" $\quad(n=101)$

McKenzie $^{12} \quad(n=566)$

Smitheringale $^{13}$

$(n=566)$

Veins compiled

East ( $\quad$ =198)

West $\quad(n=243)$

Dykes compiled

East $\quad(n=409)$

West $\quad(n=402)$

Dykes + veins compiled

Charest ${ }^{11} \quad(n=64)$

McKenzie $^{12} \quad(n=134)$

Musquodoboit Batholith

Joints

$$
\text { Dickie }^{14} \quad(n=101)
$$

Veins

MacDonald ${ }^{15} \quad(n=37)$

040

$$
\begin{aligned}
& 065 \\
& 061 \\
& 058 \\
& 062 \\
& 060
\end{aligned}
$$

313

308 ?

315

035

043

039

035

039

067
062

062

314

325

067

061

315

040

062

066

064

042

043

065

065

Halfway Cove -

Queensport Pluton

Dykes

Ham $^{16} \quad(n=45)$

Country Rocks

Joints

Smitheringale ${ }^{13}$

O'Brien ${ }^{3}$

MacDonald's's

Mafic Dykes

Owen et al. ${ }^{17}$

Calder and Barr ${ }^{18}$ quence of contours which, unlike the northwest trend, varies somewhat in overall orientation (Fig. 5). This is largely due to the relative influence of two distinct submaxima representing trends at $\approx 040^{\circ}$ (e.g., Fig. $5 \mathrm{G}, \mathrm{H}, \mathrm{L}$ ) and $\approx 062^{\circ}$ (e.g., Fig. 5 $A, B)$. The independence of each of these trends is supported by their repetition in several data sets, with no submaxima representing intermediate trends, the wide separation $\left(22^{\circ}\right)$ in the two trends and their definition by several contour intervals.

In summary, five regionally significant, steeply dipping joint trends have been recognized within the SMB. Ordered in a clockwise manner these are herein referred to as: trend 1 $\approx 040^{\circ}$, trend $2 \approx 062^{\circ}$, trend $3 \approx 315^{\circ}$, trend $4 \approx 325^{\circ}$, and trend $5 \approx 335^{\circ}$. These are consistent with the five documented trends identified in the eastern portion of the SMB (Horne $e t$ al., 1988), with the exception of a slight deviation in trend 3 and trend 5 , which were previously placed at $\approx 310^{\circ}$ and $\approx 344^{\circ}$. Joint trends consistent with those identified in this study have previously been locally identified within the SMB (Smitheringale, 1973; McKenzie, 1974; Charest, 1976). A summary of joint trends identified in the SMB is included in Table 1 .

\section{Joint description}

Joint descriptions and relationships between joints were typically not recorded and, therefore, a quantitative assessment of the character of the joint trends identified cannot be made. However, local qualitative assessment of the identified trends has recognized consistent differences in the character of NE- and NW-trending joints.

NW-trending joints are characterized by straight, continuous, planar surfaces and regular spacing (Fig. 6a,c,d) and form the dominant joint set in most outcrops within the batholith. These joints commonly dominate the topographic grain, forming long, continuous, narrow ridges (Fig. 6b,d). They commonly host greisenization, quartz \pm greisen veins and granitic dykes (Table 1; Fig. 6c,d).

Notes to Table 1.

${ }^{1}$ Regional joint trends in selected Upper Devonian to Lower Permian sandstones, southern New Brunswick and Prince Edward Island (Lajtai and Stringer, 1981).

${ }^{2}$ Dominant joint trend in the Carboniferous, Stellarton Basin (Fig. 1), K. Gillis (personal communication, 1990).

${ }^{3}$ Prominent joint trends in the Mahone Bay area (Fig. 1; O'Brien, 1988)

"Joint trends in the South Mountain Batholith for each, or part of each, NTS sheet east of the Tobeatic Fault Zone.

5Joint trends in the South Mountain Batholith for each, or part of each, NTS sheet west of the

Tobeatic Fault Zone.
${ }^{6}$ Joint trends from compiled data for the erea of the South Mountain Batholith east of the Tobeatic Fault Zone.

${ }^{7}$ Joint trends from compiled data for the area of the South Mountain Batholith west of the Tobeatic Fault Zone.

${ }^{8}$ Compiled joint + dyke + vein data for the Halifax pluton (Horne et al., 1988).

9 Compiled joint + dyke + vein data for the New Ross pluton (Horne et al., 1988).

$1^{\circ}$ Compiled joint + dyke + vein data for the Bast Dalhousie pluton (Home et al., 1988).

${ }^{11}$ Data from Charest (1979) for the portion of the South Mountain Batholith around New Ross.

${ }_{12}$ Data from McKenzic (1974) for the central portion of the South Mountain Batholith.

${ }^{13}$ Data from Smitheringale (1973) for the area along the northwest portion of the South Mountain Batholith.

14 Data from Dickie (1978) from a portion of the Musquodoboit Batholith (Fig. 1).

15 Data from MacDonald (1981), for the Musquodoboit Batholith (Fig. 1) and immedinte country rocks.

${ }^{16}$ Data from Ham (1988), for the Halfway Cove - Quecnsport pluton (Fig. 1).

${ }^{17}$ Orientations of mafic dykes along the eastem shore of Nova Scotin (Fig. 1; Owen et al., 1988). Note: trends 3 and 5 represent the range of dyke orientations dorumented while trend $4\left(326^{\circ}\right)$ represents the median of this range.

${ }^{18}$ Orientation of gabbroic dyke (Mavillette intrusion; Fig. 1) in western Nova Scotia (Calder and Barr, 1982). 

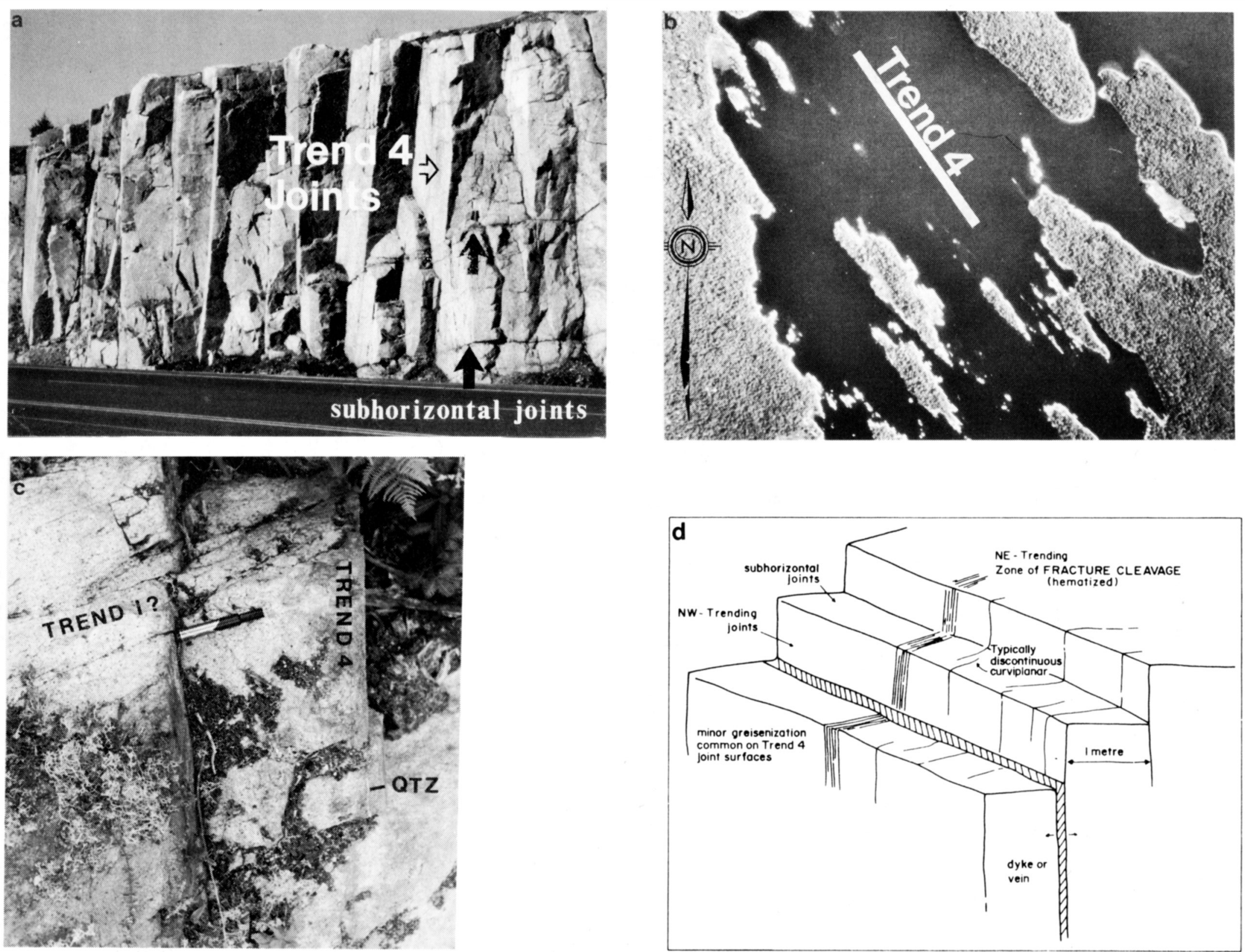

Fig. 6. (a) Photograph of a vertical exposure in the eastern part of the South Mountain Batholith (northwest part of the Halifax pluton; see Fig. 2) showing vertical, well-developed, regularly spaced NW-trending joints, vertical NE-trending joints and subhorizontal joints; (b) Aerial photograph of the southwest part of the New Ross pluton showing pronounced development of NW-trending (trend 4) joints dominating the topographic grain; (c) Photograph showing the typical character and relationship of NE- and NW-trending joints. Note the planar, regular nature of NW-trending joints, which host narrow quartz veins (QTZ), in contrast to the irregular, curviplanar, discontinuous nature of NE-trending joints; (d) Schematic diagram showing the typical character and relationship of NW-trending, NE-trending and subhorizontal joints in the South Mountain Batholith. 
NE-trending joints are typically poorly developed, curviplanar, discontinuous and irregularly spaced (Fig. 6c,d). Locally, these joints are closely spaced and form zones of 'fracture cleavage'. NE-trending joints are generally not pronounced and commonly their presence is only obvious due to weathering (especially in zones of altered fracture cleavage). These joints are typically strongly hematitized and (or) chloritized and locally control uranium and manganese oxide mineralization. Dykes and veins with this orientation are rare.

Subhorizontal joints are not well represented by the stereoplots (Fig. 5). This is probably largely due to the flat, glaciated nature of the majority of outcrop in the SMB. However, subhorizontal joints are locally recognized as significant structures in well exposed vertical sections (Fig. 6a). These joints are generally planar features and commonly host granitic dykes.

Implicit from the orientations of the various joint trends (NE, NW, horizontal) is a roughly mutually perpendicular relationship. The result is a common 'blocky' fracture pattern with NW-trending and subhorizontal joints forming stepped ridges which are cut by NE-trending joints and zones of fracture cleavage (Fig. 6d). No significant displacement is generally evident on any of the joint sets. In some cases, alteration (greisenization) and dykes or veins within NWtrending joints appear undisturbed, sealing NE-trending joints, implying that NW-trending joints postdated NE-trending joints (Fig. 6c). Elsewhere, however, mesoscale displacement of quartz veins within NW-trending joints by NEtrending joints is locally evident, implying that both NE- and NW-trending joints formed contemporaneously.

Although classification of the joint trends was not quantitative, recognition of distinct characteristics associated with NW-versus NE-trending joints suggests that the descriptions given above are applicable to the joints as a whole. A marked difference is apparent in the general character of NE-trending (trends 1 and 2) versus NW-trending (trends 3, 4, and 5) joints. Aside from the form of the joint itself, an obvious and perhaps more significant separation can be made based on the associated alteration and mineralization, i.e., NW-trending joints (trend 4 ) host greisenization and quartz \pm greisen $\pm \mathrm{Sn}$ W-Cu-Mo mineralization whereas NE-trending joints (trends 1 and 2) are generally hematitized and (or) chloritized and locally host significant $U$ and $M n$-oxide mineralization.

\section{Dykes and Veins}

The distribution and orientation of granitic dykes and veins in the SMB and corresponding stereoplots are presented in Figures 7 and 8 . Due to the relatively small number of measurements, the data were compiled into two sets reflecting the 'east' and 'west' (with respect to the Tobeatic fault zone) subdivision used for joints. The resulting stereoplots indicate that dykes in the area west of the Tobeatic fault zone define fairly strong submaxima corresponding to joint trends 4 and 5 (Fig. 7a). In contrast, dykes in the area east of the Tobeatic Fault Zone do not show any well devel- oped trends, although there is a tendency toward northeast and northwest orientations (Fig. 7b). Locally, dyke orientations define systematic map patterns (Fig. 7), some of which may reflect radial or concentric joint patterns resulting from stress associated with intrusion as outlined by Balk (1937). Such dykes may account for the random nature of the stereoplot of dykes for the area east of the Tobeatic fault zone which is dominated by the circular Halifax and New Ross plutons.

Stereonets of quartz veins from both east and west of the Tobeatic fault zone define a strong NW trend coincident with joint trend 4 (Fig. 8a,b; Table 1). This is illustrated well on a map showing the distribution and orientation of quartz veins (Fig. 8).

\section{Coincident Regional Joint, Vein and Dyke Trends and Other Units}

A review of geological studies reveals that joint, dyke and vein trends coincident with those identified in the SMB exist in various rock units throughout the Maritime region (Table 1).

\section{Ma granitoid units}

A prominent, steeply dipping joint set trending $\approx 315^{\circ}$ (SMB trend 3; Table 1) has been documented in a portion of the ca. 370 Ma Musquodoboit Batholith (Fig. 1; Dickie, 1978). Quartz veins throughout the Musquodoboit Batholith also define a $315^{\circ}$ trend (MacDonald, 1981; Table 1). Ham (1988) documented a prominent trend of $\approx 315^{\circ}$ for steeply dipping dykes within the ca. 370 Ma Halfway Cove - Queensport pluton in the eastern part of the Meguma Terrane (Fig. 1).

\section{Country rocks}

Smitheringale (1973) documented a prominent, steeply dipping joint set at $\approx 328^{\circ}$ (SMB trend 4 ) in the OrdovicianSilurian rocks along the northern side of the batholith, for which he suggested a probable syn-intrusive origin.

O'Brien (1988) stated that NW-trending 'cross joints' and NE-trending 'longitudinal joints' form the prominent joint sets in the Meguma Group in the Mahone Bay area (Fig. 1). He interpreted the presence of granitic dykes, presumably related to the $\mathrm{SMB}$, in the NW-trending joints as indicating a pre- to syn-granite origin.

Dickie (1978) documented a prominent, steeply dipping joint set trending $\approx 315^{\circ}$ (SMB trend 3 ) in the Meguma Group near the Musquodoboit Batholith; this is consistent with the joint and vein trends within the Musquodoboit Batholith.

\section{Cover rocks}

Prominent NW- and NE-trending joint sets, which collectively coincide with all five trends identified in the SMB, have been documented in Upper Devonian to Lower Permian 


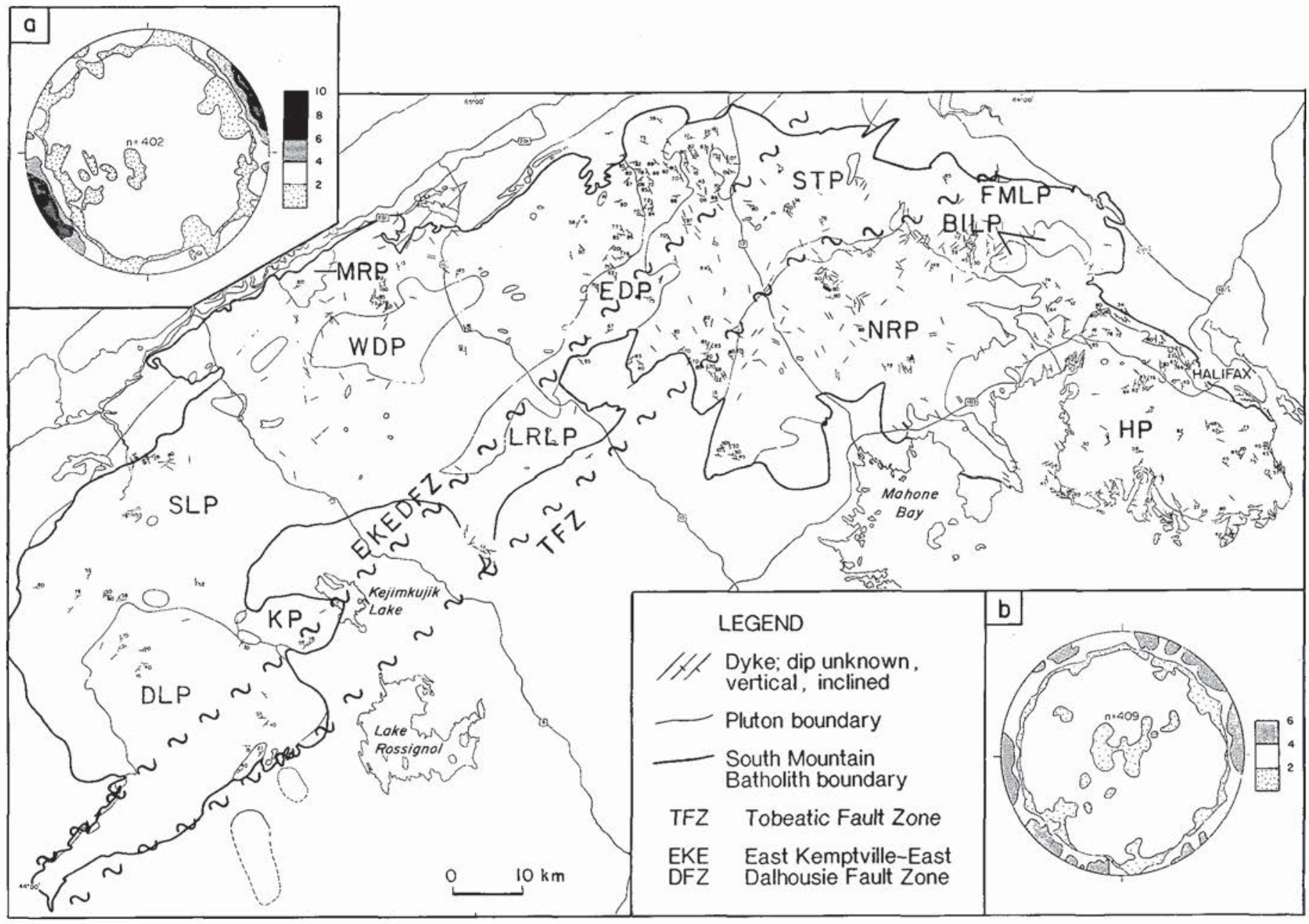

Fig. 7. Map showing the distribution and orientation of dykes in the South Mountain Batholith. Stereonets are contoured density plots of poles to dykes (in 1\% area) in the area west of the Tobeatic fault zone (a) and the area east of the Tobeatic fault zone (b). Pluton abbreviations are listed in Figure $2 b$.

sandstones in southern New Brunswick and Prince Edward Island (Fig. 1; Lajtai and Stringer, 1981; Table 1). A joint trend at $323^{\circ}$ (SMB trend 4 ) has been identified in the eastern part of the Upper Carboniferous Stellarton Graben (K. Gillis, personal communication, 1990; Table 1) and NE- and NWtrending joint sets have been documented in Lower Carboniferous limestone in the Mahone Bay area (O'Brien, 1988; Table 1).

\section{Mafic dykes}

A series of NW-trending, ca. $370 \mathrm{Ma}$ (Kempster et al., 1989) mafic dykes, referred to as the Weekend Dykes, occur along the eastern shore of Nova Scotia (Fig. 1; Table 1; Owen et al., 1988). Dyke orientations range between $310^{\circ}$ (SMB trend 3) and $342^{\circ}$ (SMB trend 5) (Owen et al., 1988), the median of which is $326^{\circ}$ (SMB trend 4).

A NW-trending $\left(330^{\circ}\right)$ gabbroic dyke (-like body), referred to as the Mavillette intrusion (Calder and Barr, 1982), occurs in southwestern Nova Scotia (Fig. 1). Absolute age dating has not been attempted; however, Calder and Barr
(1982) suggested a Late Ordovician to Early Silurian age based on geographic, mineralogical and chemical affinities with local Ordovician-Silurian volcanic rocks.

\section{Discussion}

\section{Status and age of joint trends}

The prominent joint trends identified in the SMB appear to represent regional thorough-going features in that they show no obvious relation to geologic boundaries, i.e., they are 'regional joints' (Horne et al., 1988). The regional status of these trends is also supported by their presence throughout the Maritime region. Joints related to the stresses of intrusion, first documented by Balk (1937), tend to form concentric and radial patterns and apparently are not represented by the major joint trends. However, as noted by Horne et al. (1988), such joints may contribute to the overall girdle nature of the stereoplots (Fig. 5). This is supported by local dyke orientations which may reflect such patterns.

Despite their regional nature (orientation) and occur- 


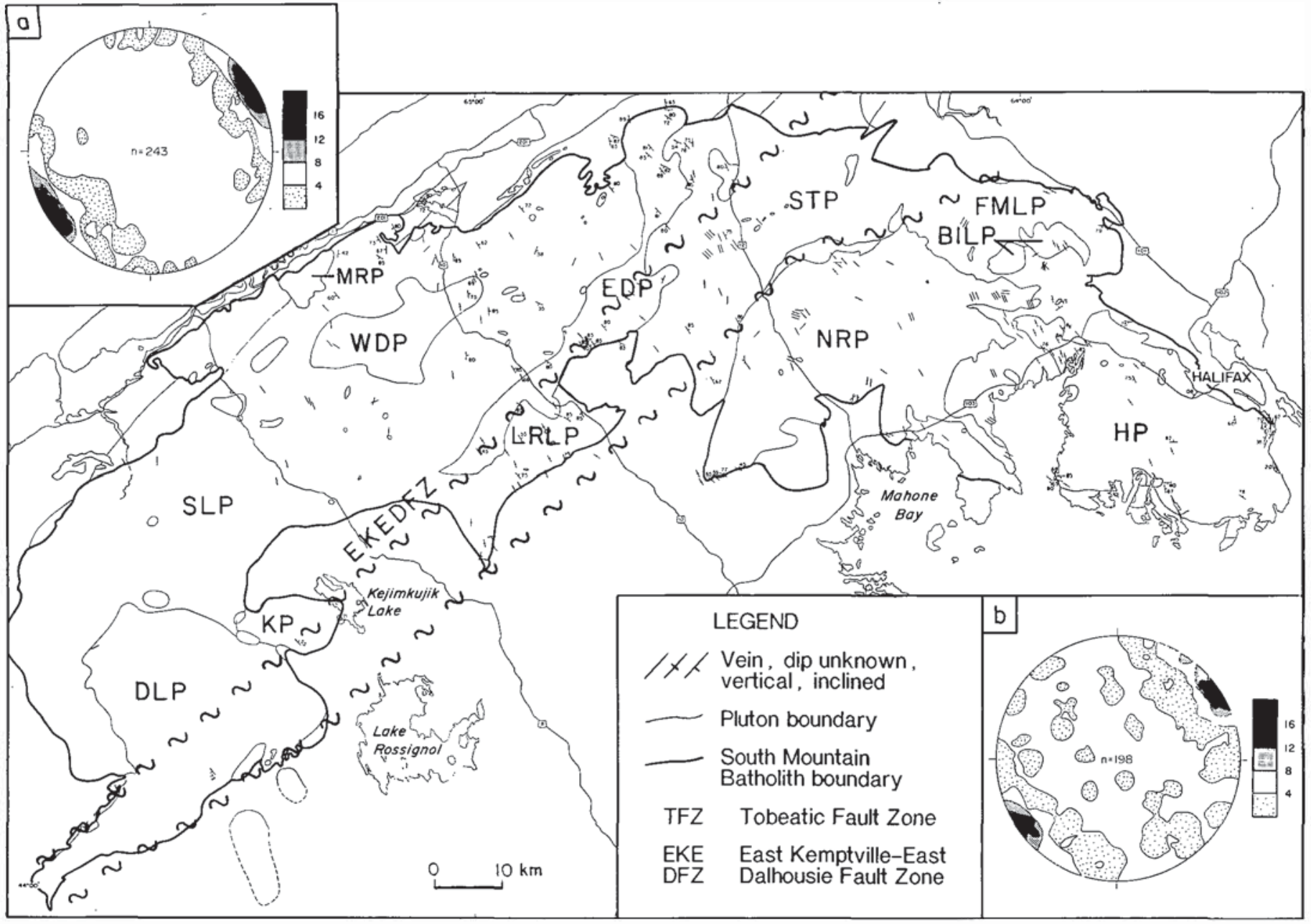

Fig. 8. Map showing the distribution and orientation of veins in the South Mountain Batholith. Stereonets are contoured density plots of poles to quartz veins (in 1\% area) in the area west of the Tobeatic fault zone (a) and the area east of the Tobeatic fault zone (b). Pluton abbreviations are listed in Figure $2 b$.

rence in overlying Carboniferous-Permian rocks, several lines of evidence indicate a primary (intrusive) age for the joint trends in the SMB. Quartz veins, and to a lesser extent dykes and hydrothermal alteration (greisenization), all presumably related to late-stage magmatic processes (Charest, 1976; Logothetis, 1984), occur within NW-trending joints (trends 3, 4 and 5; Table 1). In the case of quartz veins (trend 4), a correlation between vein mineralogy and host lithology implies repetitive development of these joints in successive intrusions (Horne et al., 1988). Coincident NW-trending joint, vein and (or) dyke trends in the ca. 370 Ma Musquodoboit Batholith and Halfway Cove - Queensport pluton and $370 \mathrm{Ma}$ mafic dykes in the metasedimentary country rocks support regionally extensive formation of NW-trending joints at that time. Granite dykes locally occur in NW-trending joints in the country rocks (O'Brien, 1988) and invasion of granite along NW-trending joints at the granite-country rock contact indicates formation of these joints prior to intrusion of the SMB. Mineralization and hydrothermal alteration related to late-stage intrusions is localized along NE-trending faults and fractures (e.g., Millett Brook U deposit, Chatterjee et al.,
1982; New Ross Mn deposit, O’Reilly, 1988, in press; East Dalhousie U prospect, O'Reilly et al., 1982), implying that these structures developed during batholith emplacement. A primary origin for both NW- and NE-trending joints is supported by crosscutting relationships which imply contemporaneous formation. A primary intrusive origin for the regional joint trends denotes a 'primary-regional' status for these structures. Repetition of these trends in overlying Upper Devonian to Lower Permian rocks throughout the Maritime region (Table 1) implies a protracted history of repetitive joint formation from prior to granite intrusion until the Permian.

\section{Joint formation}

Previous assessment of the joint trends in the SMB (Horne et al., 1988) suggested that trend 4 represented tension fractures and trends 3 and 5 attending vertical shear fractures of small dihedral angle, reflecting NW-horizontal compression. Trend 2 was interpreted to represent either release fractures or de-stretching fractures related to regional 
uplift, augmented by vertical magmatic pressure. Trend 1 was not well understood and thought to be possibly related to NE-trending faults. This model would reflect initial, regional-scale northwest compression and subsequent relaxation parallel to trend 4, and offers an explanation for the variability in character of NW- and NE-trending joints.

The above interpretation explains the NW-trending joints (trends 3,4, and 5). Regional NW-horizontal compression is consistent with regional NW transpression inferred during the period of granite intrusion. The interpretation of trend 4 as tension joints, parallel to maximum stress, is supported by the presence of veins and dykes (Figs. 7, 8), presumably filling dilatant structures reflecting NE extension. This interpretation is also consistent with the orientation of compression $\left(\approx 145^{\circ}\right)$ determined for a segment of the CobequidChedabucto fault system (Fig. 9a). The interpretation of trends 3 and 5 as attending shear joints of small dihedral angle is based mainly on their conjugate geometry about trend 4 (Fig. 9b). Limited, isolated evidence supports a conjugate shear origin for these joints: (i) Quartz veins trending $154^{\circ}$ (trend 5) at the Turner tin occurrence (Farley, 1978) have associated minor (pinnate) veins trending $127^{\circ}$ (Fig. 9c), similar to quartz veins within the country rocks in the Mahone Bay area which O'Brien (1988) interpreted as reflecting sinistral shear during emplacement. Sinistral displacement is consistent with the sense of shear implied for trend 5 (Fig. $9 \mathrm{~b}$ ); and (ii) NW-trending shearing reflected by patterns of aligned megacrysts (Fig. 4a; Abbott, 1989) roughly parallel trends 3 and 5 and display a sense of shear coincident with that interpreted for joint trends 3 and 5 (see inset Fig. 4a). The occurrence of shear joints with a small dihedral angle was discussed by Muehlberger (1961) who indicated that such joints are transitional in character between extensional and shear joints. This interpretation explains the occurrence of dykes and veins within these joints (Table 1) which indicates an extensional character.

Several inconsistencies in the above model are apparent with regard to NE-trending joints: (i) trend $2\left(062^{\circ}\right)$, considered to be release joints, is not actually perpendicular to the interpreted maximum compression direction (trend 4); (ii) evidence supports a primary (intrusive) origin for both NWand NE-trending joints, implying that both formed under similar stress; and (iii) similar characteristics of trends 1 and 2 (i.e., alteration, absence of veins or dykes) suggest a common origin. An alternative, and more plausible explanation for the origin of NE-trending joints relates them to regional-scale NE-trending faults. Joint trends 1 and 2 are consistent with the orientations of expected $\mathrm{P}$ and $\mathrm{R}$ shears (Riedel shear geometry) associated with dextral displacement on the major NE-trending faults in the batholith (Fig. 10). The sense of displacement on these faults has not been resolved, however, evidence supports at least a component of dextral shear (see faults below). The interpretation of trend 1 as $\mathrm{P}$ shears is supported by coincident shear fractures documented within a segment of the East Dalhousie fault (Horne et al., 1988; Fig. 10).

In summary, we propose that the five regional joint trends may represent two separate joint systems: (i) NW-

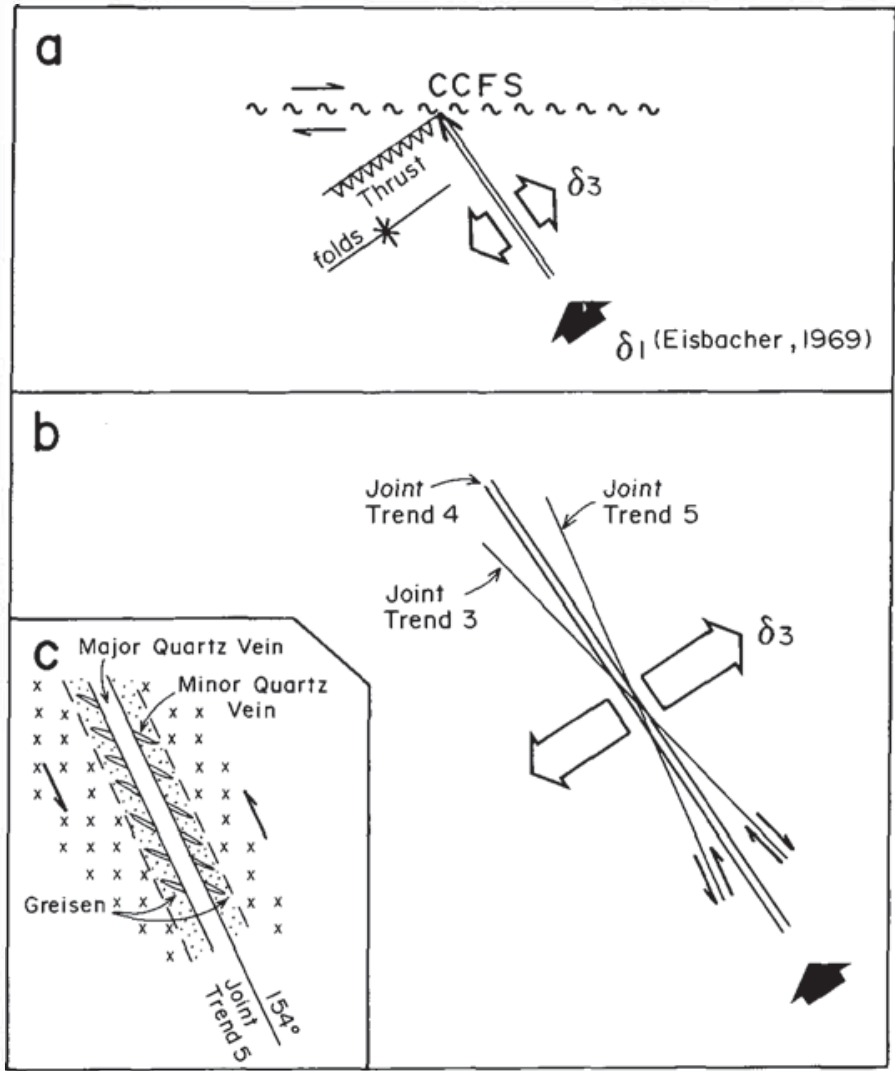

Fig. 9. Interpretation of NW-trending joint trends (3-5). (a) Schematic diagram of general NW-transpressional stress regime affecting the Meguma Terrane during the Late Paleozoic. CCFS Cobequid-Chedabucto fault system; (b) interpretation of NWtrending joint trends, with trend 4 as extensional joints and trends 3 and 5 as conjugate shear joints; (c) schematic diagram of a syntectonic quartz vein coincident with joint trend 5 at the Turner tin prospect (after Farley, 1978). Vein geometry implies sinistral movement along trend 5 .

trending, Appalachian-perpendicular, tension joints and associated conjugate shear fractures reflecting regional, northwest compression; and (ii) NE-trending joints related to regional-scale Appalachian-parallel dextral shearing. Although NE-trending faults are not consistent with northwest compression, similar orogen-parallel faulting is documented throughout the Appalachian Orogen (Fig. 1) during the middle to late Paleozoic and likely reflects the influence of the pronounced NE-trending Appalachian structural grain on fault orientations. Repetitive formation of the primary-regional joint trends in the SMB and in overlying Carboniferous and Permian rocks implies a similar orientation of regional stress throughout this period. Primary-regional, orogen-parallel and orogen-perpendicular joint trends reflecting regional tectonic stress, similar to those discussed above, are documented in intrusions in Arizona (Heidrick and Titley, 1982; Rehrig and Heidrick, 1972; Titley et al., 1986), British Columbia (Linnen and Williams-Jones, 1987) and Peru (Pitcher, 1978). In Arizona and Peru an extended period of joint formation is demonstrated by repetitive joint formation in intrusions spanning several million years. 


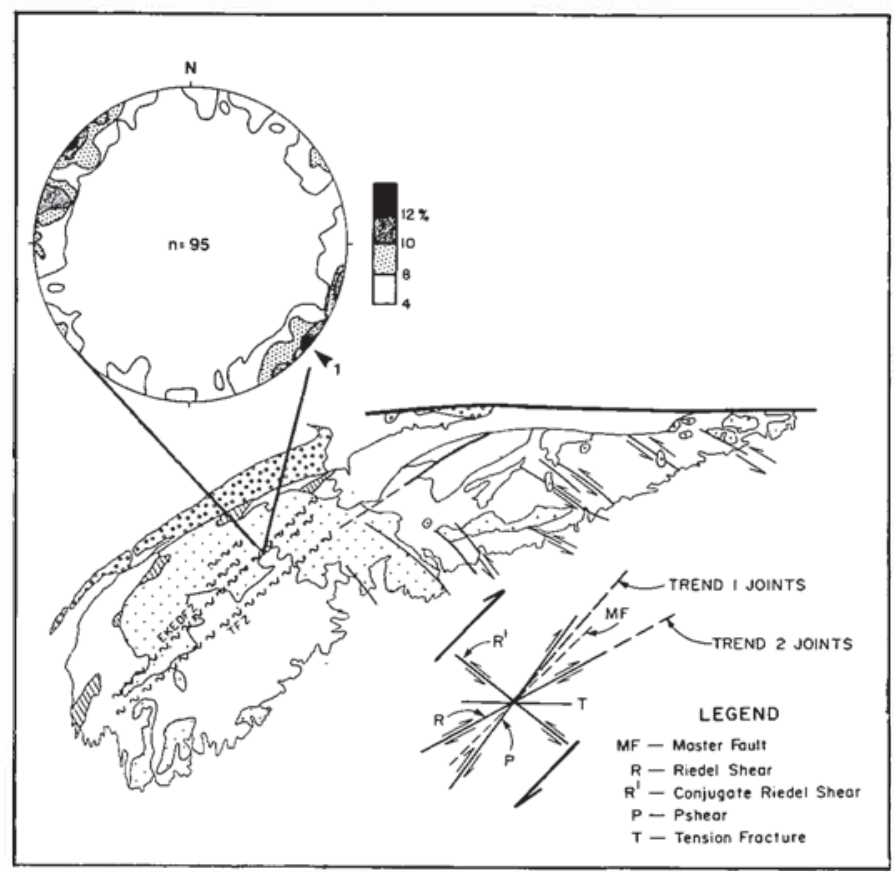

Fig. 10. Diagram showing the relationship of joint trends 1 and 2 with expected $\mathrm{P}$ and $\mathrm{R}$ shears (Riedel shear geometry) associated with regional NE-trending dextral faults and the concurrence of joint trend 1 with observed shear fractures ( $P$ shears) associated with a portion of the East Dalhousie fault (stereoplot).

\section{FAULTS}

\section{General Statement}

Several previously undocumented fault and shear zones have been identified in the SMB by the authors. Additional studies by Smith (1985), Kontak et al. (1986) and O'Reilly $(1987,1988)$ have also documented several fault and shear zones affecting the batholith.

Faults in the SMB can be loosely divided into two groups on the basis of the dominant deformational style: (i) brittle faults, and (ii) shear zones. This subdivision is based on field observations and limited published accounts, and is intended only to emphasize the more apparent generalizations about the fault zones.

Brittle faults typically display heterogeneous deformation, with narrow (metre scale) zones of intense deformation, characterized by breccia, microbreccia and cataclasite, within a broader (tens to hundreds of metres) zone of moderate deformation, characterized mainly by abundant shear (slickensided) fractures. Intense hematitization and (or) chloritization is pervasive throughout all brittle fault zones. Narrow, chloritic, pseudotachylite (?) dykes are commonly associated with brittle faults.

Shear zones are characterized by variably penetrative brittle-ductile to ductile deformational textures, including C$\mathrm{S}$ fabrics, mylonite, blastomylonite, ultramylonite and rare rodded mylonite gneiss. Minor brittle deformation associated with these faults is generally restricted to deformation of earlier ductile structures and commonly associated with a silicification event. Hematitization and chloritization, which are ubiquitous in brittle faults, are conspicuously lacking or related to late brittle deformation in shear zones.

\section{NE-trending Faults and Shear Zones}

Several NE-trending faults and shear zones, including the Molly Upsim fault, East Dalhousie fault, Manganese Mines fault zone, Beaver Lake fault, Tobeatic Lake shear zone, Rushmeer Lake shear zone and East Kemptville shear zone form a belt of parallel structures which collectively transect the western part of the SMB (Fig. 2a). The Rushmeer Lake and Tobeatic Lake shear zones lie along the trace of the proposed Tobeatic fault zone (Fig $2 \mathrm{~b}$; Giles, 1985) and along strike projection of the East Dalhousie fault and East Kemptville shear zone implies a single structure, herein referred to as the East Kemptville - East Dalhousie fault zone (Fig. 2b). This 'belt' of NE-trending faults is characterized by brittle deformation in the central part of the batholith and ductile deformation at the western end (Fig. 2a). The transition from brittle to ductile features coincides with increasing regional metamorphic grade in the country rocks (Fig. 1) and is reflected by thermal conditions attending several regional thermal-tectonic events. ${ }^{40} \mathrm{Ar} /{ }^{99} \mathrm{Ar}$ dating indicates partial to complete resetting of muscovite $\left(<350^{\circ} \mathrm{C}\right)$ and complete resetting of feldspar subsequent to intrusion in the western end of the batholith and surrounding rocks (Reynolds et al., 1987; Dallmeyer and Keppie, 1987; Kontak et al., 1989; Soehl et al., 1989), whereas similar dating in the eastern part of the batholith indicates muscovite was not reset and $\mathrm{K}$-feldspar was only partially reset subsequent to intrusion (Reynolds et al., 1987).

The age of northeast-trending faults has not been unequivocally determined. However, several lines of evidence indicate that these faults experienced a protracted history from prior to batholith emplacement until Permian. The linear shape of the East Dalhousie pluton (Fig. 2b), coincident with the East Dalhousie fault, suggests that it was localized along this structure (Horne et al., 1988, 1990, this study), implying that faulting occurred in surrounding stage 1 plutons prior to intrusion of the East Dalhousie pluton. Faulting prior to intrusion of the East Dalhousie pluton is supported by more intense deformation of the host stage 1 plutons. Moderate deformation of the East Dalhousie pluton, local fault contacts with adjacent stage 1 plutons and local lithologic discontinuity within the East Dalhousie pluton across the East Dalhousie fault (Fig. 2a; i.e., fine-grained leucomonzogranite southeast of the fault and coarse-grained leucomonzogranite to the northwest) indicate later movement on this structure. A similar sequence of faulting and intrusion has been documented by O'Reilly (1987, in press) for a series of small intrusions associated with the Manganese Mines fault zone (Fig. 2a). As well, Kontak et al. (1990) suggested that the East Kemptville shear zone, which is locally coincident with the linear northwestern contact of the batholith (Fig. 2a), may represent a reactivated structure which was prominent during emplacement of the batholith. 
The above examples demonstrate that NE-trending faults, in particular the East Kemptville - East Dalhousie fault zone, were active during the time of granite intrusion. Localization of granite-related mineralization along these faults further supports syn-intrusive development of these structures.

Kontak et al. $(1989,1990)$ interpreted a spectrum of ${ }^{40} \mathrm{Ar} /$ ${ }^{39} \mathrm{Ar}$ and $\mathrm{Rb} / \mathrm{Sr}$ dates in southwestern Nova Scotia (Zentilli and Reynolds, 1985; Kontak et al., 1989, 1990; Soehl et al., 1989 ) as indicating a protracted history of movement along the East Kemptville shear zone from ca. 350 Ma until the Permian. Additionally, Dallmeyer and Keppie (1987) identify thermal overprinting events, some related to NE-trending, dextral shear, throughout southwestern Nova Scotia. Prolonged activity on NE-trending faults is supported by similar faults in overlying Carboniferous sedimentary rocks east of the SMB (e.g., RF, RCF, and MMR, Fig. 1; Giles and Boehner, 1982), which are likely part of the same regionalscale fault system.

Difficulty in determining a sense of movement on brittle faults, a rarity of exposed ductile zones and a general lack of apparent offset of map units (at map-scale) inhibit a clear evaluation of the sense of movement on the NE-trending faults. Slickensides observed on fractures in the East Dalhousie, Beaver Lake and Molly Upsim faults (Fig. 2a) are predominantly vertical, indicating at least some component of vertical displacement. Vertical displacement could explain the apparent lack of significant displacement of granitegranite and granite-country rock boundaries. Vertical displacement is also consistent with uplift following intrusion of the batholith.

The apparent lack of offset of map units implies that horizontal displacement was not substantial. As discussed above, the character and orientation of regional NE-trending joint trends in the SMB (trend $1 \approx 040^{\circ}$ and trend $2 \approx 062^{\circ}$ ) are consistent with $R^{\prime}$ and $P$ shears (Riedel shear geometry) associated with dextral displacement along NE-trending faults. C-S fabrics in the East Kemptville shear zone (Kontak et al., 1986) indicate a component of dextral strike-slip displacement. Dextral strike-slip displacement on these faults is consistent with regional, Appalachian-parallel faulting during the Upper Paleozoic (Fig. 1; Webb, 1969; Yeo and Ruixiang, 1987).

\section{NW-trending Faults}

Two major northwest-trending faults have been identified in the SMB, namely the Herring Cove fault and Roxbury Brook fault (Fig. 2a). These faults roughly parallel several other faults in the eastern portion of the Meguma Terrane (Fig. 1).

The age of NW-trending faults in the SMB is not well constrained. However, regional, NW-trending structures are inferred to have influenced emplacement of the batholith (Horne et al., 1988, 1990, this study). Apparent sinistral displacement on the Herring Cove fault is suggested by the relative offset of map units in the Halifax area (Horne et al., 1988; Fig. 2a). Similar relative offset could, however, be explained by a component of dip-slip movement. A component of sinistral displacement on the Roxbury Brook fault is suggested by apparent offset of the contact of the West Dalhousie pluton along this structure (Fig. 2a). However, this is not confirmed at the granite-country rock contact along the northern side of the batholith. Sinistral offset on the these faults is consistent with the sense of displacement on the series of parallel faults along the eastern shore of Nova Scotia (Fig. 1). Although the relationship between NW- and NEtrending faults is unknown, the relative orientation and sense of displacement of NW-trending faults is consistent with expected conjugate Riedel shear faults ( $\left.R^{\prime}\right)$ associated with dextral displacement on the NE-trending faults (Fig. 10).

\section{Influence of Structure on Mineralization}

The systematic joint and fault patterns outlined above, which were developing apparently during emplacement and crystallization of the SMB, have strongly influenced the localization of mineralization in the batholith. As discussed above, contrasting styles of mineralization occur in NE- and $\mathrm{NW}$-trending structures. NW-trending primary-regional joints, in particular trend 4, host mineralized (Sn-W-Cu-Mo) quartzgreisen veins whereas NE-trending faults and associated fractures are typically hematitized and (or) chloritized and commonly host uranium and manganese mineralization (Fig. 11). The mineralized quartz-greisen veins are generally associated with the more evolved stage 2 plutons (Fig. 11), resulting from local infilling of early formed, regional, NWtrending dilatant joints by late-stage mineralizing fluids. Control on mineralized quartz-greisen veins systems by primary-regional fractures in granite systems has been documented for $\mathrm{Cu}$ porphyry deposits in Arizona (Titley et al., 1986; Rehirg and Heidrich, 1972) and a stockwork Mo deposit in British Columbia (Linnen and Williams-Jones, 1987). Mineralized NE-trending faults and related fractures occur in both stage 1 and stage 2 plutons (Fig. 11) although the source of mineralization is generally interpreted to have been related to late-stage intrusions (Chatterjee et al., 1982; O'Reilly, 1987, in press; O'Reilly et al., 1982).

The East Kemptville Sn deposit (Fig. 11) exhibits several levels of structural control. The host leucogranite, which is responsible for mineralization, has an elongate, NE-trending form implying intrusion along the East Kemptville shear zone (Kontak et al., 1990). In addition, quartz-vein and greisen trends in the deposit show preferred NE- and NWorientations, indicating structural control on their localization; Richardson (1983) documented principal quartz-vein and greisen trends of $120^{\circ}$ and $030^{\circ}$ in the exploration decline and Kontak et al. (1986) documented principal NE trends for both quartz veins $\left(\approx 50^{\circ}\right)$ and greisens $\left(\approx 30^{\circ}\right)$ throughout the deposit.

The Tobeatic $\mathrm{Pb}-\mathrm{Zn}$ prospect (Fig. 11) is hosted by the Tobeatic Lake shear zone (Corey and Horne, 1989), however, the relationship between mineralization and the SMB has not been established. 


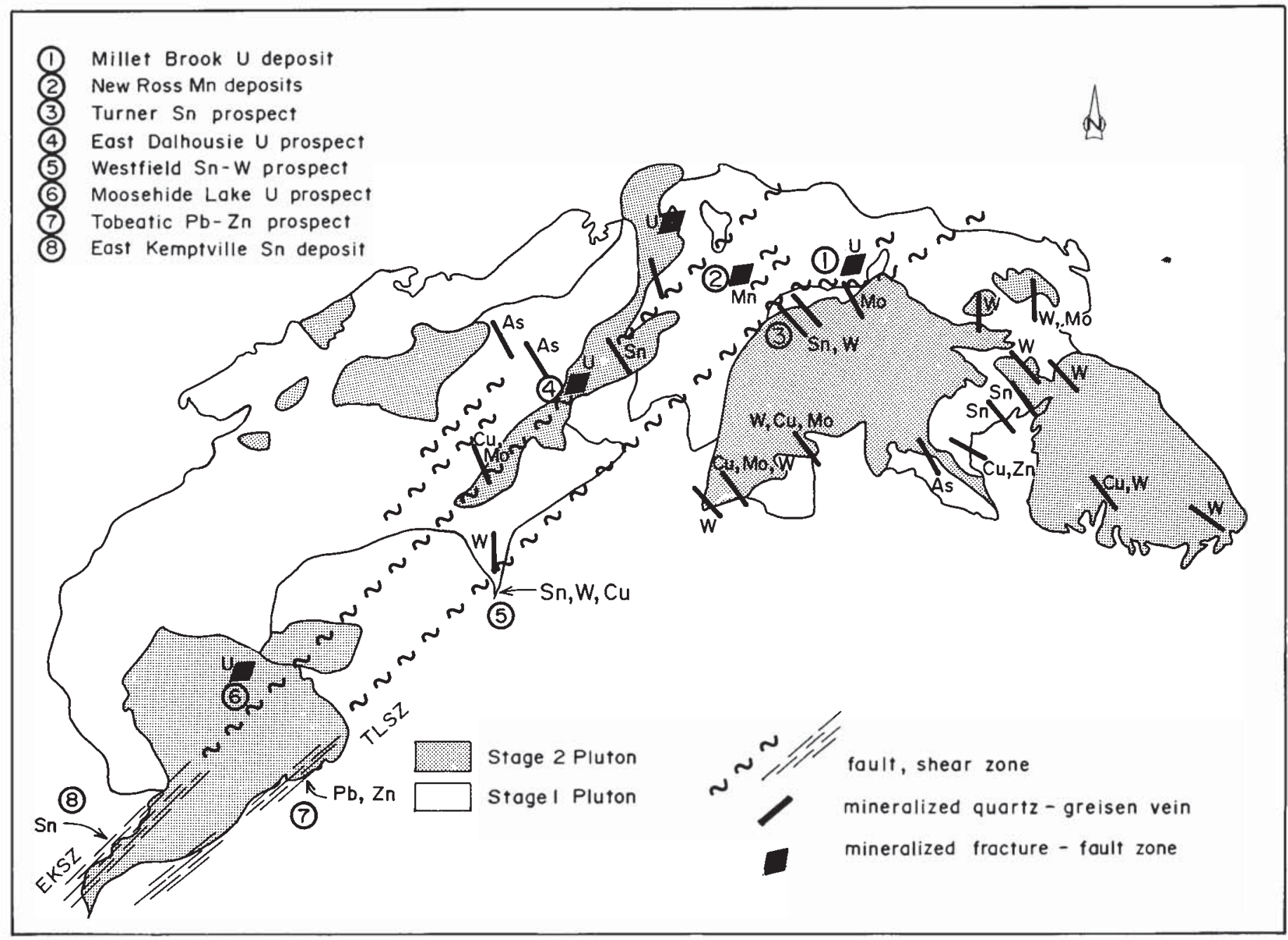

Fig. 11. Map showing the distribution of mineralized NW-trending quartz-greisen veins and NE-trending faults and associated fractures within South Mountain Batholith.

\section{EMPlacement of THE SMB}

\section{Localization of the Batholith}

The coalescence of large, composite batholiths such as the SMB implies a structural control on their ascent and localization by deep-seated, crustal-scale faults (Pitcher, 1978, 1979; Pitcher and Bussell, 1977; Castro, 1986). As outlined above, a system of regional, NE-trending faults (e.g., TFZ, EKEDFZ; Fig. 2b) transecting the Meguma Terrane were active during granite intrusion and may reflect such a crustal-scale structure along which the SMB was localized. A similar inference was first made by (Giles, 1985) who suggested the Tobeatic fault zone may represent a reactivated pre-Devonian crustal fault zone along which the SMB may have been emplaced. NE-trending faults were active during granite intrusion, localizing some stage 2 plutons, and experienced a protracted history of movement up to the Permian. A proposed account of regional NE-trending fault development and intrusion of the SMB in presented in Figure 12.

\section{Three-dimensional Geometry and Emplacement of the SMB}

Interpretation of regional gravity (Fig. 13a) suggests that the SMB is roughly 'mushroom shaped', consisting of a large slab-like body approximately 5 to $10 \mathrm{~km}$ thick with a main stalk reaching to a depth of 20 to $25 \mathrm{~km}$ in the area of New Ross pluton (Douma, 1978). This model was applied to accommodate a general theory on the origin of the SMB which suggested that it was a single, comagmatic intrusion with monzogranitic plutons reflecting autointrusion of residual melt into a solidified granodiorite envelope (McKenzie and Clarke, 1975). Recent detailed petrographic and geochemical work, however, has shown that the SMB consists of thirteen plutons (Fig. 2a), several of which display petrographic-geochemical zonation related to in situ differentiation. In addition, multivariate statistical analysis of geochemical data suggests that all plutons are not strictly cogenetic (Horne et al., 1989; MacDonald et al., 1992), implying that the SMB reflects the coalescence of numerous, separate intrusions. This concept is supported by limitations imposed by an 

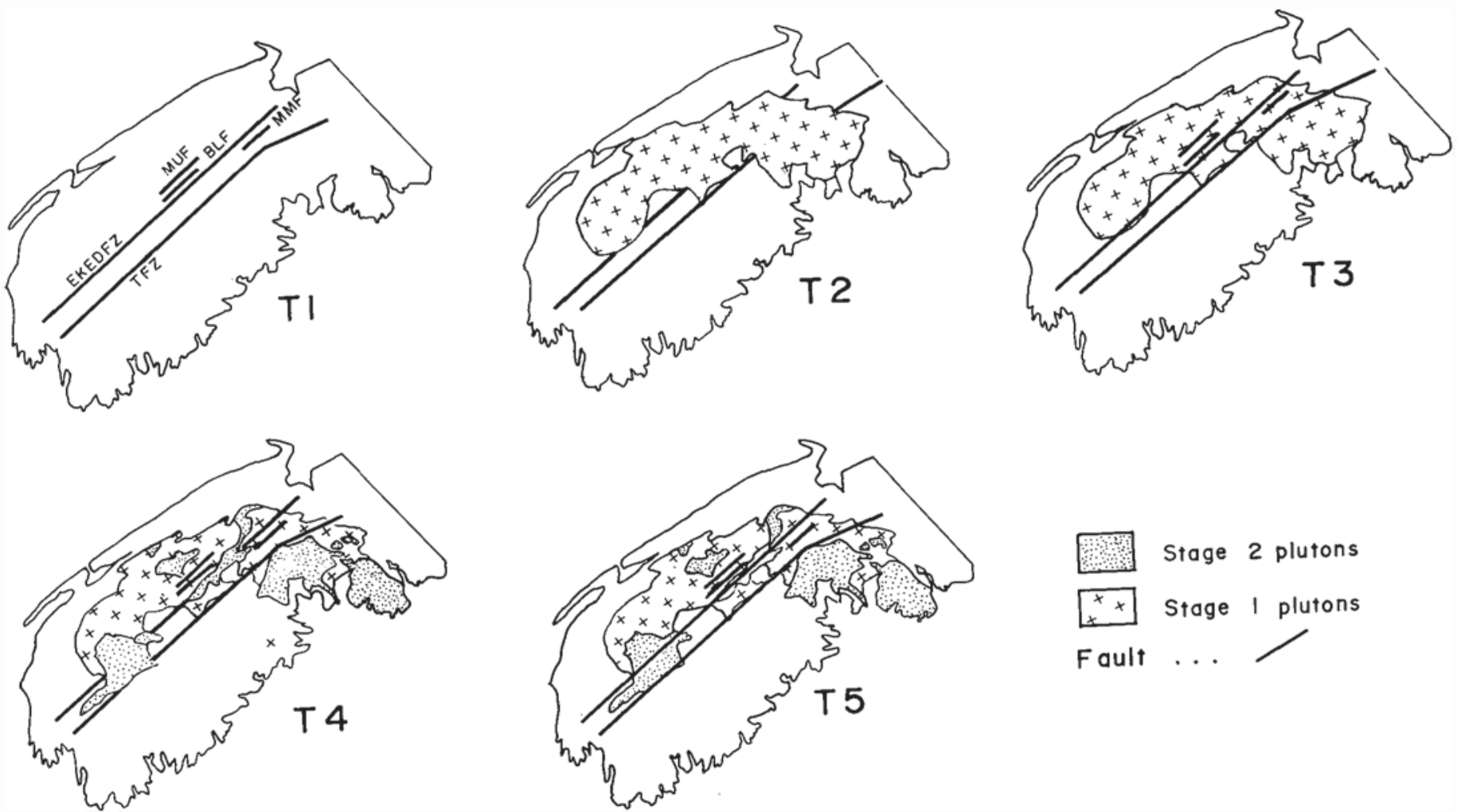

Fig. 12. Succession of maps outlining the proposed sequence of faulting and intrusion of the South Mountain Batholith: (T1) NEtrending, crustal-scale faults existed in southwest Nova Scotia prior to intrusion of the SMB; (T2) intrusion of stage 1 plutons, localized along NE-trending faults; (T3) movement along NE-trending faults, locally affecting stage 1 plutons; (T4) intrusion of stage 2 plutons, some of which were localized along NE-trending faults within stage 1 plutons; (T5) continued movement along NE-trending faults, affecting both stage 1 and stage 2 plutons.

interpreted vertical profile of the SMB (Fig. 13b); the complex geology of the SMB, including zonation of plutons, coupled with the slab-like geometry is difficult to accommodate with a single intrusion.

\section{Final Emplacement}

\section{Forceful injection}

Limited evidence of possible local forceful injection of the SMB is found in the enclosing country rocks in two areas. (i) A NW-trending 'transverse' anticline and syncline occur adjacent to the SMB just north of Halifax (Faribault, 1908; Fig. 3). These structures may reflect localized deformation resulting in reorientation of the country rocks during granite invasion (Wright, 1931; Clarke and Chatterjee, 1988). (ii) Gentle, regional warping of the stratigraphy and structure in the country rocks, coincident with the boundary of the batholith, occurs along the western margin of the SMB (Fig. 3) suggesting possible lateral thrusting related to 'ballooning' of the batholith. This is supported by the trend of aligned megacrysts within the batholith which parallel the boundary of the batholith (Fig. 3).

\section{Stoping}

The common occurrence of xenoliths, locally discordant contacts with the country rocks and the general lack of distortion of regional structure and stratigraphy in the country rocks (Fig. 3), either lateral or vertical, imply that at the current level of exposure, stoping was the dominant mode of emplacement (Wright, 1931; McKenzie and Clarke, 1975; Cooke and Milligan, 1980; Clarke and Chatterjee, 1988; Horne et al., 1990). Examination of the granite-country rock contact indicates that stoping was strongly influenced by bedding and bedding-normal joints in the country rocks which has resulted in a rectilinear contact pattern observable at the metre scale (Fig. 14). Extrapolating on a regional scale, the general shape of the SMB can largely be approximated by NE- and NW-trending linear contacts (Fig. 15b), implying that emplacement was advanced by regional-scale block stoping influenced by regional-scale NE- and NW-trending structures. Similar regional-scale stoping has been interpreted in the Ackley Granite in Newfoundland by Miller and Tuach (1989) who referred to this process as 'mega block' stoping.

An assessment of internal contacts within the SMB 

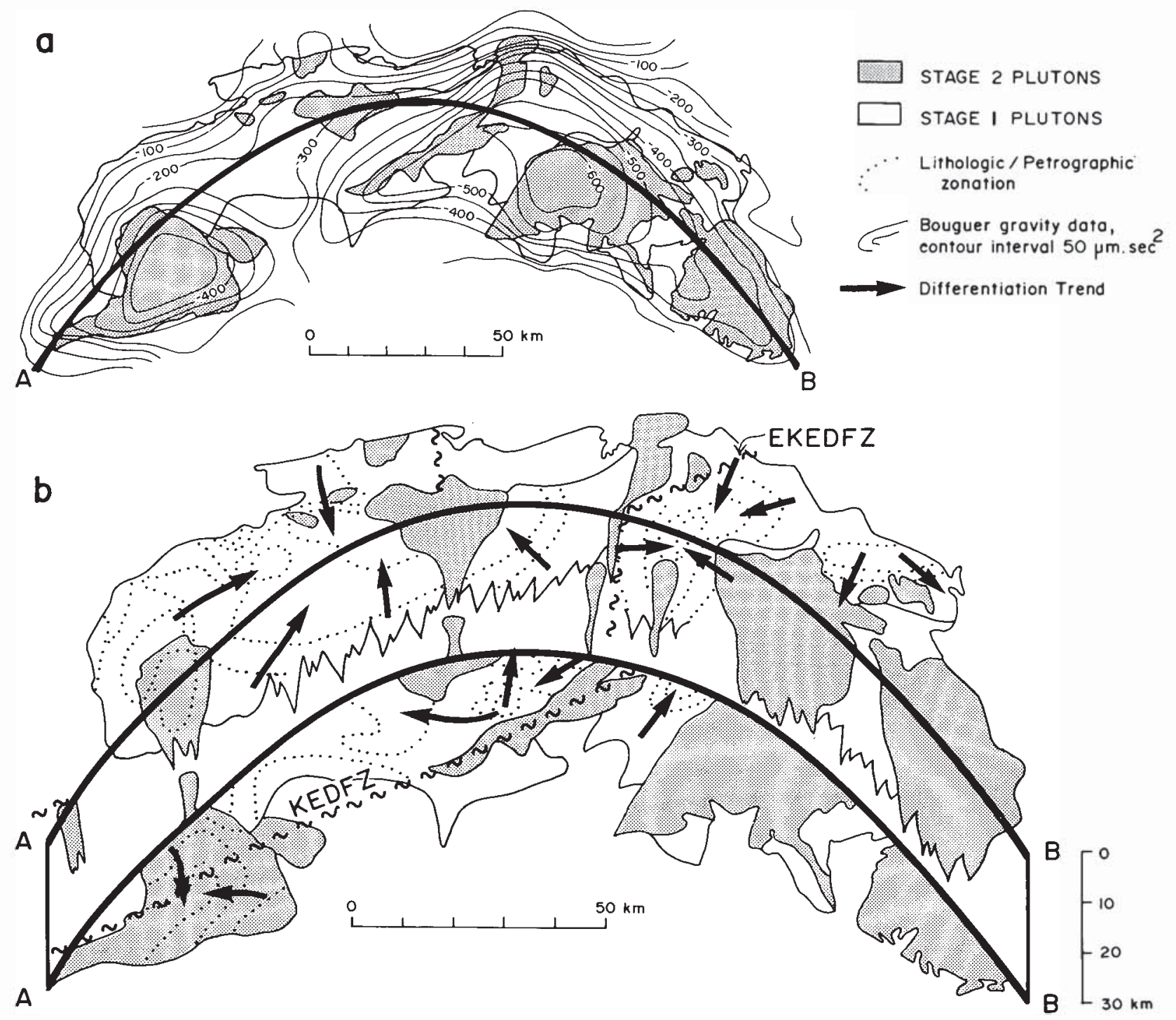

Fig. 13. (a) Map of contoured bouguer gravity data over the South Mountain Batholith (from Keppie, 1979). Note correlation between gravity lows and stage 2 plutons. (b) Interpreted three-dimensional geometry through a section of the South Mountain Batholith [line A-B shown in (a)]. Interpretation incorporates gravity data and petrographic-geochemical zonation of plutons expressed at the current level of exposure. Lithologic/petrographic zonation from Horne et al. (1989, 1991); Chatterjee and Horne (1991).

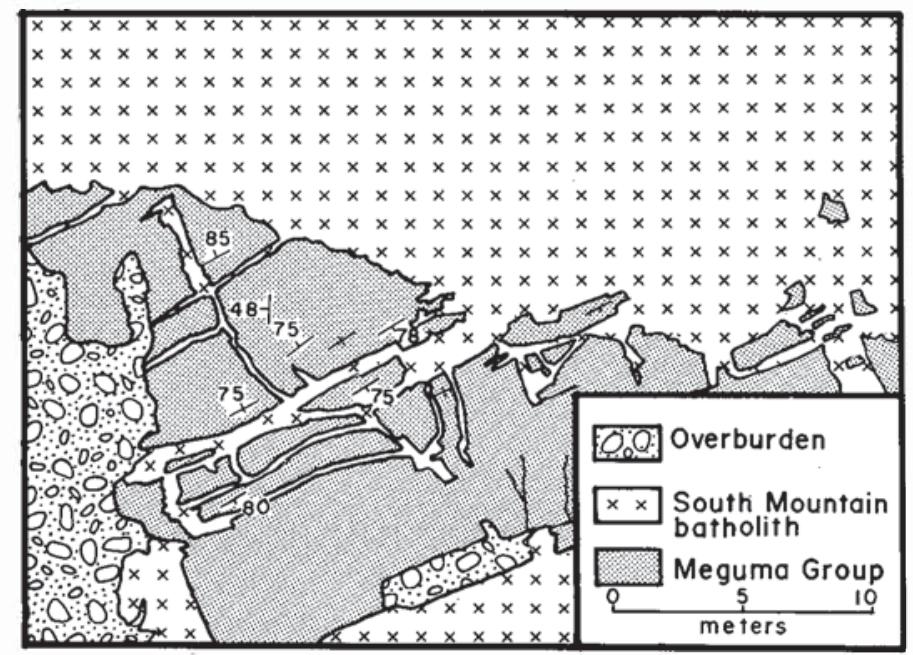

indicates that NE- and NW-trending linear granite-granite contacts are common (Horne et al., 1988, 1990; Fig. 15a). These linear contacts define the boundary of stage 1 and stage 2 plutons as well as internal contacts in composite stage 2 plutons and, although most common in the eastern part of the SMB, are found throughout the batholith (Fig. 15a). Some of the NE-trending linear contacts are explained by localization of stage 2 plutons along faults, e.g., the East Dalhousie pluton. Elsewhere these linear granite-granite contacts, which locally result in rectilinear intrusions, implies that NE- and

Fig. 14. Sketch of an area of the granite-country rock contact at Portuguese Cove (after Cooke and Milligan, 1980). Note how granite invasion was strongly influenced by bedding and bedding normal joints. 


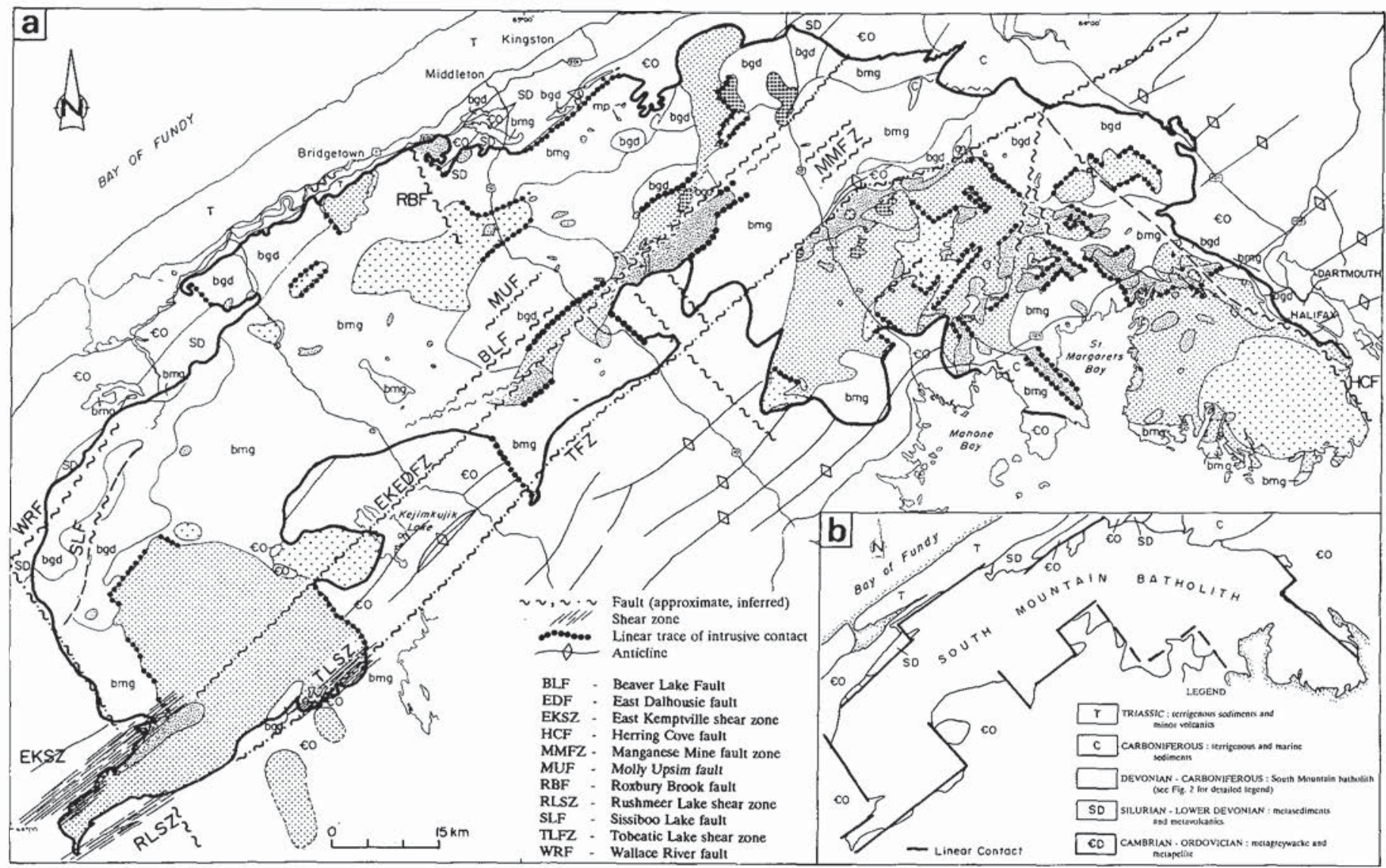

Fig. 15. Map of the South Mountain Batholith highlighting linear NW- and NE-trending granite-country rock and granite-granite contacts. Note the resultant blocky intrusive pattern, particularly in the composite stage 2 plutons. Inset map demonstrates how the general shape of the batholith, which is broadly arcuate, can be defined by a blocky pattern of NE- and NW-trending contacts.

NW-trending structures developed in early intrusions influenced emplacement of later intrusions (Horne et al., 1988, 1990; Corey, 1988).

The above discussion indicates that final emplacement of the SMB was strongly influenced by pre- and syn-emplacement, regional NE- and NW-trending structures. An analogous interpretation of fracture control on intrusion has been documented for the Coastal Batholith of Peru, where a repetitive, orthogonal system of Andean-parallel and Andean-normal fractures controlled pluton emplacement over a period of $30 \mathrm{Ma}$ (Moore and Agar, 1985; Bussell and Pitcher, 1985; Bussell, 1976; Knox, 1974).

\section{Conclusions}

Emplacement of the SMB post-dated regional deformation of the Lower Paleozoic country rocks associated with the Middle Devonian Acadian Orogeny. However, structural features in the SMB reflect the influence of weak, regional, NW-directed transpression during emplacement. Repetition of these structures in overlying sedimentary rocks indicates continued transpression until the Permian. This regional stress influenced development of several structures in the batholith, including primary flow features, joint, dyke and vein orientations and faults.
Primary flow features within the SMB include schlieren, xenolith and (or) megacryst concentrations, megacryst-xenolith alignment and biotite alignment. These structures reflect differential flow within the magma during emplacement which is probably largely due to internal stress related to intrusion. However, regional patterns defined by aligned megacrysts imply the influence of moderate, external regional stress.

Stereonet plots of joint orientations in the SMB show two $\mathrm{NE}$ and three NW regional joint trends within the SMB. The occurrence of granite-related hydrothermal alteration and (or) coincident veins and dykes trends indicate primaryregional status for these joint trends. NW-trending joints at $315^{\circ}, 325^{\circ}$ and $335^{\circ}$, are interpreted as tension joints and attending conjugate shear joints of small dihedral angle reflecting NW horizontal compression. Quartz veins and to a lesser degree, dykes are hosted by NW-trending joints. NEtrending joints at $040^{\circ}$ and $062^{\circ}$, are interpreted as $\mathrm{P}$ and $\mathrm{R}$ shears (Riedel shear geometry) associated with dextral displacement on NE-trending faults.

Several NE- and NW-trending faults occur within the SMB, and the NE-trending faults form a belt which transects the batholith. Several stage 2 plutons have been localized along NE-trending faults, demonstrating that these structures were active during emplacement. ${ }^{40} \mathrm{Ar} /{ }^{39} \mathrm{Ar}$ dating and along- 
strike continuation of NE-trending faults in overlying carboniferous rocks indicate protracted activity along these structures.

Primary-regional joint and fault trends have influenced the style and localization of granite-related mineralization in the SMB, with two important structural styles being recognized: (i) NW-trending mineralized (Sn-W-Cu-Mo) quartzgreisen veins, and (ii) NE-trending mineralized (U, Mn) faults and associated fractures.

Intrusion and final emplacement of the SMB was strongly influenced by primary-regional structures. Ascent and localization of the SMB likely occurred along the NE-trending system of faults, which were active during granite emplacement and responsible for localization of some stage 2 intrusions. Final emplacement of the SMB was largely accomplished by stoping which was strongly influenced by NE- and NW-trending structures in the country rock and early units of the batholith, resulting in rectilinear intrusive patterns.

The joint and fault trends in the SMB are recognized as regional trends throughout the Maritime region, and transect Permian and older rock units. Recognition of the primary status of these structures with respect to the SMB provides a significant minimum time marker for their development. Repetition of trends implies a fixed tectonic stress from the time of emplacement of the batholith until the Permian.

\section{ACKNOWLedgements}

The authors are indebted to A.K. Chatterjee for proposing the South Mountain Batholith as part of the Canada-Nova Scotia Mineral Development Agreement 1984-89 and for his continued support of related studies. Our understanding of the South Mountain Batholith and its geological setting has greatly benefited from discussions with our colleagues at the NSDNR, in particular D. Kontak, G. O'Reilly, A. Chatterjee, $P$. Smith and R. Boehner. Figures were prepared by the cartographic section of the NSDNR, photographic work was provided by $\mathrm{R}$. Morrison and tables were prepared by $\mathrm{B}$. MacDonald. This paper is published with the permission of the director of the Mineral Resources Division, Nova Scotia Department of Natural Resources.

AввотT JR., R.N. 1989. Internal structures in part of the South Mountain Batholith, Nova Scotia, Canada. Geological Society of America Bulletin, 101, pp. 1493-1506.

BALK, R. 1937. Structural behaviour of igneous rocks. Geological Society of America, Memoir 535, 69 p.

BozhNeR, R.C. 1991. Seismic interpretation, potential overthrust geology and mineral deposits in the Kennetkook Basin, Nova Scotia. In Mines and Minerals Branch Report of Activities 1990. Edited by D.R MacDonald. Nova Scotia Department of Mines and Energy, Report 91-1, pp. 37-47.

- In press. The Role of Windsor Group in the structural Development of Carboniferous basins in Nova Scotia. Atlantic Geology.

Bussell, M.A. 1976. Fracture control of high-level plutonic contacts in the Coastal Batholith of Peru. Proceedings of the Geological Association, 87, pp. 237-246.
Bussell, M.A. and Pitcher, W.S. 1985. The structural controls of batholith emplacement. In Magmatism at a Plate Edge, The Peruvian Andes. Edited by W.S. Pitcher, M.P. Atherton, E.J. Cobbing and R.D. Beckinsale. Blackie, Glasgow, pp. 167 176.

CAlder, L.M. and BArr, S.M. 1982. Petrology of the Mavillette intrusion, Digby County, Nova Scotia. Maritime Sediments and Atlantic Geology, 18, pp. 29-40.

Castro, A. 1986. Structural pattern and ascent model in the Central Extremadura batholith, Hercynian belt, Spain. Journal of Structural Geology, 8, pp. 633-645.

Charest, M.H. 1976. Petrology, geochemistry, and mineralization of the New Ross area, Lunenburg County, Nova Scotia. Unpublished M.Sc. thesis, Dalhousie University, Halifax, Nova Scotia, 154 p.

Chatterjee, A.K. and HAM, L.J. 1991. U-Th-Pb systematics of the South Mountain batholith, Nova Scotia. In Program with Abstracts, Atlantic Geoscience Society Colloquium, Amherst, Nova Scotia, February, 1991.

Chatterjee, A.K. and Horne, R.J. 1991. Variations in LIL elements, HFS elements and REEs within the Davis Lake pluton, southwestern Nova Scotia. In Program with Abstracts, Atlantic Geoscience Socicty Colloquium, Amherst, Nova Scotia, February, 1991.

Chatterjee, A.K., Robertson, J., and Pollock, D. 1982. Geochemistry and the distribution of uranium mineralization at Millet Brook, South Mountain Batholith, Nova Scotia. In Mineral Resources Division Report of Activities 1981. Edited by K.A. Mills. Nova Scotia Department of Mines and Energy, Report 82-1, pp. 57-67.

Clarke, D.B. and Chatterjee, A.K. 1988. Physical and chemical process in the South Mountain batholith. In Recent advances in the geology of granite-related mineral deposits. Edited by R.P. Taylor and D.F. Strong. Canadian Institute of Mining and Metallurgy, Special Volume 39, pp. 223-233.

Clarke, D.B. and Muecke, G.K. 1980. Igneous and metamorphic geology of southern Nova Scotia. Geological Association of Canada-Mineralogical Association of Canada, Field Trip Guidebook, 21, 101 p.

Cooke, H.B.S. and Milligan, G.C. 1980. Magmatic stoping at Meguma-granite contact near Halifax, Nova Scotia. Geological Association of Canada-Mineralogical Association of Canada, Field Trip Guidebook, 11, 7 p.

CoRey, M.C. 1988. An occurrence of metasomatic aluminosilicates related to high alumina hydrothermal alteration within the South Mountain Batholith, Nova Scotia. Maritime Sediments and Atlantic Geology, 24, pp. 83-95.

Corey, M.C. and Horne, R.J. 1989. Polymetallic - precious metal potential of the Tobeatic Fault Zone in southwestern Nova Scotia. In Mines and Mineral Branch Report of Activities 1988, Part B. Edited by Y. Brown and D.R. MacDonald. Nova Scotia Department of Mines and Energy, Report 89-1, pp. 27 36.

Dallmeyer, R.D. and KepPIe, J.D. 1987. Polyphase late Paleozoic tectonothermal evolution of the southwest Meguma Terrane, Nova Scotia: evidence from ${ }^{40} \mathrm{Ar} /{ }^{39} \mathrm{Ar}$ mineral ages. Canadian Journal of Earth Sciences, 24, pp. 1242-1254.

DiCKIE, J.R. 1978. Geological, mineralogical and fluid inclusion studies at the Dunbrack lead-silver deposit, Musquodoboit Harbour, Halifax County, Nova Scotia. Unpublished B.Sc. thesis, Dalhousie University, Halifax, Nova Scotia, 43 p.

DoumA, M. 1978. Gravitational interpretation and modelling of 
the South Mountain batholith, Nova Scotia. Unpublished B.Sc. thesis, Dalhousie University, Halifax, Nova Scotia, 36 p.

EisBacher, G.H. 1969. Displacement and stress field along part of the Cobequid Fault, Nova Scotia. Canadian Journal of Earth Sciences, 6, pp. 1095-1104.

Fairbault, E.R. 1908. City of Halifax sheet, Map No. 68. Geological Survey of Canada, Publication No. 1019.

FARLEY, E.J. 1978. Mineralization at the Turner and Walker deposits. Unpublished M.Sc thesis, Dalhousie University, Halifax, Nova Scotia, 192 p.

GiLes, P.S. 1985. A major post-Visean shear zone - new perspectives on Devonian and Carboniferous rocks of southern Nova Scotia. In Guide to the granites and mineral deposits of southwestern Nova Scotia. Edited by A.K. Chatterjee and D.B. Clarke. Nova Scotia Department of Mines and Energy, Open File Report 650, pp. 233-264.

Giles, P.S. and Bozhner, R.C. 1982. Geological map of the Shubenacadie and Musquodoboit basins, central Nova Scotia. Nova Scotia Department of Mines and Energy, Map 821 , scale $1: 50,000$.

HAM, L.J. 1988. The mineralogy, petrology and geochemistry of the Halfway Cove-Queensport Pluton, Nova Scotia, Canada. Unpublished M.Sc. thesis, Dalhousie University, Halifax, Nova Scotia, 183 p.

HARPER, C.L. 1988. On the nature of time in the cosmological perspective. Unpublished Ph.D. thesis, Oxford University, Oxford, United Kingdom, 508 p.

HeIDRICK, T.L. and Titley, S.R. 1982. Fracture and dike patterns in Laramide plutons and their structural and tectonic implications. In Advances in Geology of Porphyry Copper Deposits. Edited by S.R. Titley. University of Arizona Press, Tucson, Arizona, pp. 73-91.

Horne, R.J., Corey, M.C., Ham, L.J., and MacDonald, M.A. 1988. Primary and secondary structural features in the eastern portion of the South Mountain Batholith, southwestern Nova Scotia: implications for regional stress orientations during intrusion. Maritime Sediments and Atlantic Geology, 24, pp. 71-82.

1989. Lithogeochemical variation within the biotite-rich envelope rocks of the eastern South Mountain Batholith: implications for its intrusive and post-intrusive history. In Mines and Minerals Branch Report of Activities 1988, Part B. Edited by Y. Brown and D.R. MacDonald. Nova Scotia Department of Mines and Energy, Report 89-1, pp. 37-50.

1990. Emplacement of the South Mountain Batholith: structural and intrusive considerations. In Atlantic Geoscience Society Colloquium, Program with Abstracts, 1990, Wolfville, Nova Scotia.

-1991. Variation in the mafic mineral content of the Scrag Lake pluton, South Mountain batholith: evidence for a zoned pluton. In Mines and Minerals Branch, Report of Activities 1990. Edited by D.R. MacDonald. Nova Scotia Department of Mines and Energy, Report 91-1, pp. 49-60.

Kempster, R.M.F., Clarke, D.B., Reynolds, P.H., and ChatTERJEE, A.K. 1989. Late Devonian lamprophyric dykes in the Meguma Zone of Nova Scotia. Canadian Journal of Earth Sciences, 26, pp. 611-613.

Keppie, J.D. 1979. Bouguer Gravity Anomaly map of Nova Scotia, Nova Scotia Department of Mines and Energy, scale 1: 500,000 .

1982. The Minas Geofracture. In Major Structural Zones and Faults of the Northern Appalachians. Edited by P. StJulien and J. Beland. Geological Association of Canada, Special Paper 24, pp. 263-280.

KNox, G.J. 1974. The structure and emplacement of the Rio Fortaleza Centred acid complex, Ancash, Peru. Journal of the Geological Society of London, 130, pp. 295-308.

Kontak, D.J., Mulja, T., and Hingston, R. 1986. The East Kemptville Sn deposit: preliminary results from recent mapping. In Tenth Annual Open House and Review of Activities. Edited by J.L. Bates and D.R. MacDonald. Nova Scotia Department of Mines and Energy, Information Series No. 12, pp. 97-103.

Kontak, D.J., Cormier, R.F., Reynolds, P.H., and TAYlor, K. 1989. Preliminary results of $\mathrm{Rb} / \mathrm{Sr}$ and ${ }^{40} \mathrm{Ar} /{ }^{39} \mathrm{Ar}$ geochronological investigations, East Kemptville leucogranite, southwestern Nova Scotia: Evidence for a ca. $370 \mathrm{Ma}$ age of emplacement and multiple tectono-thermal overprinting events. In Mines and Minerals Branch Report of Activities 1989, Part A. Edited by D.R. MacDonald and K.A. Mills. Nova Scotia Department of Mines, Report 89-3, pp. 41-47.

Kontak, D.J., O'Reilly, G.A., and Chatterjee, A.K. 1990. The southwest Nova Scotia tin domain, Yarmouth County, Nova Scotia: implications for tin metallogeny in the Meguma Terrane, Nova Scotia. In Mines and Minerals Branch Report of Activities 1989, Part B. Edited by D.R. MacDonald. Nova Scotia Department of Mines and Energy, Report 90-1, pp. 1332.

LAJtAi, E.Z. and Stringer, P. 1981. Joints, tensile strength and preferred fracture orientation in sandstones, New Brunswick and Prince Edward Island, Canada. Maritime Sediments and Atlantic Geology, 17, pp. 70-87.

Linnen, R.L. and Williams-Jones, A.E. 1987. Tectonic control of quartz vein orientations at the Trout Lake stockwork molybdenum deposit, southern British Columbia: implications for metallogeny in the Kootenay area. Economic Geology, 82, pp. 1283-1293.

Logothetis, J. 1984. The mineralogy and geochemistry of metasomatized granitic rocks from occurrences in the South Mountain Batholith. Unpublished M.Sc. thesis, Dalhousie University, Halifax, Nova Scotia, 359 p.

MacDonald, M.A. 1981. The mineralogy, petrography and geochemistry of the Musquodoboit Batholith. Unpublished M.Sc. thesis, Dalhousie University, Halifax, Nova Scotia, 272 p.

MacDonald, M.A. and HaM, L.J. 1988. Preliminary geological map of Gaspereau Lake, NTS sheets 21 A/15 and part of 21H/ 02. Nova Scotia Department of Mines and Energy, Open File Map 88-016, scale 1:50,000.

1989. Preliminary geological map of Bridgetown, NTS sheet 21 A/14. Nova Scotia Department of Mines and Energy, Open File Map 89-016, scale 1:50,000.

MacDonald, M.A., Horne, R.J., Corey, M.C., and HaM, L.J. 1992. An overview of recent bedrock mapping and follow-up petrological studies of the South Mountain Batholith, southwestern Nova Scotia, Canada. Atlantic Geology, 28, pp. 7 28.

MAWER, C.K. and White, J.C. 1987. Sense of displacement on the Cobequid-Chedabucto fault system, Nova Scotia, Canada. Canadian Journal of Earth Sciences, 24, pp. 217-223.

McKenzie, C.B. 1974. Petrology of the South Mountain Batholith, Nova Scotia. Unpublished M.Sc. thesis, Dalhousie University. Halifax, Nova Scotia, 164 p.

McKenzie, C.B. and Clarke, D.B. 1975. Petrology of the South 
Mountain Batholith, Nova Scotia. Canadian Journal of Earth Sciences, 12, pp. 1209-1218.

Miller, H.G. and TAUCH, J. 1989. Gravity and magnetic signatures of the Ackley Granite Suite, southeastern Newfoundland: implications for magma emplacement. Canadian Journal of Earth Sciences, 26, pp. 2697-2709.

Moore, N.D. and AGAR, R.A. 1985. Variations along a batholith: the Arequipa segment of the Costal Batholith of Peru. In Magmatism at a Plate Edge, The Peruvian Andes. Edited by W.S. Pitcher, M.P. Atherton, E.J. Cobbing and R.D. Beckinsale. Blackie, Glasgow, pp. 108-118.

Muehlberger, W.R. 1961. Conjugate joint sets of small dihedral angle. Journal of Geology, 69, pp. 211-219.

NANCE, R.D. 1987. Dextral transpression and late Carboniferous sedimentation in the Fundy Coastal Zone of southern New Brunswick. In Sedimentary basins and basin-forming mechanisms. Edited by C. Beaumont and A.J. Tankard. Canadian Society of Petroleum Geologists, Memoir 12, pp. 363-377.

O'Brien, B.H. 1988. A study of the Meguma Terrane in Lunenburg County, Nova Scotia. Geological Survey of Canada, Open File 1823.

O'Reilly, G.A. 1987. Geology of the Dean and Chapter manganese mine and surrounding area, Lunenburg County, Nova Scotia. In Mines and Minerals Branch Report of Activities 1986. Edited by J.L. Bates and D.R. MacDonald. Nova Scotia Department of Mines and Energy, Report 87-1, pp. 99-105.

- 1988. South Mountain Batholith project: mineral deposit studies. In Mines and Minerals Branch Report of Activities 1988, Part A. Edited by D.R. MacDonald and Y. Brown. Nova Scotia Department of Mines and Energy, Report 88-3, pp. 105-107.

- In press. Petrographic and geochemical evidence for a hypogene origin of granite-hosted, vein-type manganese mineralization at the New Ross Manganese Deposit, Lunenburg County, Nova Scotia, Canada. Economic Geology.

O'Reilly, G.A., FARLey, E.J., and Charest, M.H. 1982. Metasomatic-hydrothermal mineral deposits of the New Ross-Mahone Bay area, Nova Scotia. Nova Scotia Department of Mines and Energy, Paper 82-2, 96 p.

Owen, J.V., Greenouhg, J.D., HY, C., and Ruffman, A. 1988. Xenoliths in a mafic dyke at Popes Harbour, Nova Scotia: implications for the basement to the Meguma Group. Canadian Journal of Earth Sciences, 25, pp. 1464-1471.

Pitcher, W.S. 1972. The Coastal Batholith of Peru: some structural aspects. In 24th International Geological Congress. Edited by J.E. Gill. Section 2, pp. 156-163.

1978. The anatomy of a batholith. Journal of the Geological Society of London, 135, pp. 157-182.

- 1979. The nature, ascent and emplacement of granitic magmas. Journal of the Geological Society of London, 136, pp. 627-662.

Pitcher, W.S. and Bussell, M.A. 1977. Structural control of batholithic emplacement in Peru: a review. Journal of the
Geological Society of London, 133, pp. 249-256.

Rehrio, W.A. and Heidrick, T.L. 1972. Regional fracturing in Laramide stocks of Arizona and its relationship to porphyry copper mineralization. Economic Geology, 67, pp. 198-213.

Reynolds, P.H., Elias, P., Muecke, G.K., and Grist, A.M. 1987. Thermal history of the southwestern Meguma Zone, Nova Scotia, from an ${ }^{40} \mathrm{Ar} /{ }^{39} \mathrm{Ar}$ and fission track dating study of intrusive rocks. Canadian Journal of Earth Sciences, 24, pp. 1952-1965.

Richardson, J.M. 1983. Geology and geochemistry of the East Kemptville greisen-hosted tin deposit, Yarmouth County, Nova Scotia. Unpublished M.Sc. thesis, University of Toronto, London, Ontario, 232 p.

SмITH, P.K. 1985. Mylonitization and fluidized brecciation in southern Nova Scotia. In Mines and Minerals Branch Report of Activities 1984. Edited by K.A. Mills and J.L. Bates. Nova Scotia Department of Mines and Energy, Report 85-1, pp. 119-133.

SMITH, T.E. 1975. Layered granitic rocks at Chebucto Head, Halifax County, Nova Scotia. Canadian Journal of Earth Sciences, 12, pp. 456-463.

Smitheringale, W.G. 1973. Geology of parts of Digby, Bridgetown, and Gaspereau Lake map areas, Nova Scotia. Geological Survey of Canada, Memoir 375, 78 p.

Soehl, T.P., O'Reilly, G.A., Clarke, D.B., and Reynolds, P.J. 1989. The graphite-bearing, Kempt Snare Lake greisenized leucogranite cupola, Yarmouth County, Nova Scotia. In Mines and Minerals Branch Report of Activities 1988, Part B. Edited by Y. Brown and D.R. MacDonald. Nova Scotia Department of Mines and Energy, Report 89-1, pp. 51-70.

Titley, S.R., Thompson, R.C., Haynes, F.M., Manske, S.L., RoBison, L.C., and WhiTE, J.L. 1986. Evolution of fractures and alteration in the Sierrita Esperanza hydrothermal system, Pima county, Arizona. Economic Geology, 81, pp. 343-370.

Utting, J., Keppie, J.D., and Giles, P.S. 1989. Palynology and stratigraphy of the lower Carboniferous Horton Group, Nova Scotia. In Contributions to Canadian Paleontology. Geological Survey of Canada, Bulletin 396, pp. 117-143.

Weвв, G.W. 1969. Paleozoic wrench faults in Canadian Appalachians. In North Atlantic - Geology and Continental Drift. Edited by M. Kay. American Association of Petroleum Geologists, Memoir 12, pp. 754-786.

Wright, W.J. 1931. Data on the method of granite intrusion in Nova Scotia. Transactions of the Royal Society of Canada, 3rd series, 25, pp. 309-327.

Yeo, G.M. and Ruixinng, G. 1986. Late Carboniferous dextral movement on the Cobequid-Hollow fault system, Nova Scotia: evidence and implications. In Current Research, Part A. Geological Survey of Canada, Paper 86-1, pp. 399-410.

Zentilli, M. and ReYnolds, P.H. 1985. ${ }^{40} \mathrm{Ar} /{ }^{39} \mathrm{Ar}$ dating of micas from the East Kemptville tin deposit, Yarmouth County, Nova Scotia. Canadian Journal of Earth Sciences, 22, pp. 1546-1548. 